\title{
A HIERARCHICAL FACTOR ANALYSIS OF A SAFETY CULTURE SURVEY
}

\author{
A Thesis \\ by \\ CHRISTOPHER B. FRAZIER
}

\begin{abstract}
Submitted to the Graduate School
Appalachian State University

in partial fulfillment of the requirements for the degree

MASTER OF ARTS
\end{abstract}

May 2011

Department of Psychology 
A Thesis

by

CHRISTOPHER B. FRAZIER

May 2011

\section{APPROVED BY:}

Timothy D. Ludwig

Chairperson, Thesis Committee

Brian Whitaker

Member, Thesis Committee

Shawn Bergman

Member, Thesis Committee

James C. Denniston

Chairperson, Department of Psychology

Edelma D. Huntley

Dean, Research and Graduate Studies 
Copyright by Christopher B. Frazier 2011

All Rights Reserved

Permission is hereby granted to the Appalachian State University Belk Library and to the Department of Psychology to display and provide access to this thesis for appropriate academic and research purposes 


\section{FOREWORD}

This thesis is written in accordance with the style of the Publication Manual of the American

Psychological Association (6th Edition) as required by the Department of Psychology at Appalachian State University. 


\section{DEDICATION}

I wish to dedicate this thesis to my parents, Norman and Carolyn Frazier. Their enduring support has made my graduate school experience possible. 


\section{ACKNOWLEDGEMENTS}

First, I would like to thank my thesis chair, Dr. Timothy D. Ludwig, for his continual patience and advice throughout my thesis process. I would also like to thank my other two committee members, Dr. Brain Whitaker and Dr. Shawn Bergman for their guidance through this process. Dr. Whitaker deserves additional acknowledgment, as he was a consummate guide throughout my data analysis. Dr. Scott Geller and Safety Performance Solutions deserve special thanks for allowing me to analyze their safety culture survey. I am honored to add to Dr. Geller's prominent contributions in organizational safety research. 
A Hierarchical Factor Analysis of a Safety Culture Survey

Christopher B. Frazier

Appalachian State University 


\begin{abstract}
A positive safety culture can lead to a decrease in organizational injury and disaster statistics as well as the costs associated from those injuries. A safety culture literature review suggested there were some constructs that needed expansion and inclusion within safety culture measurements. A 92-item survey was constructed by subject matter experts based on their knowledge and literature. The resulting survey was administered to 25,574 workers across five multinational organizations in five different industries. The data set was split in half before exploratory and hierarchical confirmatory factor analyses were conducted. These analyses revealed Safety Culture as a second-order latent variable with four first-order factors consisting of Management Concern, Personal Responsibility for Safety, Peer Support for Safety, and Safety Management Systems. Additionally, twelve indicators were found: three on Management Concern, three on Personal Responsibility, two on Peer Support, and four on Safety Management Systems. The resulting safety culture model addresses gaps in the literature by pinpointing core factors which make up a safety culture.
\end{abstract}




\section{A Hierarchical Factor Analysis of a Safety Culture Survey}

Safety culture has received increased attention since the Occupational Safety and Health (OSH) Act was passed in 1970. The OSH Act protects all workers from health and safety related issues in their working environments. Protecting workers from injuries is important on a social level (Montero, Araque, \& Rey, 2009), but there is also a positive economic impact in reducing safety hazards (Occupational Safety and Health Administration, 2003). To increase awareness of safety, organizations are looking for a way to monitor the good, the bad, and the ugly of their safety culture. That is, organizations need a tool that systematically illustrates what supports safety within their safety culture and what should be improved.

Recent reviews of safety culture measures have revealed a host of potential factors which could make up a safety culture (Flin, Mearns, O’Connor, \& Bryden, 2000; Guldenmund, 2000). However, there is still little consensus regarding what the core factors of safety culture are. The purpose of the current research was to determine the core factors, as well as the structure of those factors that make up a safety culture, and establish which factors add meaningful value by factor analyzing a safety culture survey.

\section{Safety Culture Background}

According to a 2006 report from the Bureau of Labor Statistics, organizations in the United States lose up to 170 billion dollars annually due to work-related injuries and unsafe working environments (as cited in Towers Watson, 2010). The National Safety Council's (NSC) most recent statistics show annual losses can be as high as 183 billion dollars (National Safety Council, 2010). The NSC additionally reported each worker must increase his or her productivity on average $\$ 1,250$ to make up for a single injured worker. 
Takala (2002) gave a report at the sixteenth World Congress on Safety and Health at Work, where he presented economic and competitive disadvantages organizations sustain as a result of lost work time due to injury or disease. Takala reported that the shareholder price was higher for organizations that have an effective safety and health management system. He also described how the competitive advantage for a country was inversely related to the number of per capita fatal accidents within that country.

Injuries and the associated costs decrease over time when an organization views safety as an investment rather than an expense (OSHA, 2003). A small near-term investment in safety programs- can potentially prevent large, future costs due to a disaster. These costs could include workers compensation, lost-time work, or substantial legal costs. Additionally, public reputations could be damaged if the incident was significant, and thus the possibility to hurt a company in the marketplace (Myers, 2010). In attempts to reduce injuries, and costs, organizations could attempt to develop a positive safety culture. Behm, Viltri, and Kleinsorge (2004) argue that safety cultures, which include prevention and detection programs, can increase employee awareness, while reducing costs associated with injuries.

Organizations are now investing more time and resources into the protection of their employees. This has not always been the case, as workplace safety has been historically neglected by organizations to enhance profitability. Safety concerns have increased after a series of disastrous events in the early 1900s through the present (e.g. Hawks Nest tunnel, Harshbarger, 2009; Stalnaker, 2006; Triangle Shirtwaist factory fire, von Drehle, 2003). These large-scale incidents have decreased over time, but even with increased attention, these organizational disasters are still evident today. 
There was a great deal of discourse around the concept of "safety culture," following a series of mining incidents in 2010. The Upper Big Branch Mine in West Virginia had previously been cited for numerous safety violations (Maher, Powers, \& Hughes, 2010). In April 2010, a methane buildup resulted in an explosion and mine collapse. In the following days, there was speculation surrounding the safety culture of workers, as well as those who held leadership positions at this mine. Even when supervisors assured employees working conditions were safe, the miners knew their safety equipment (e.g., the methane detectors and ventilation systems) did not consistently operate (Berkes \& Langfitt, 2010). Miners observed engineers rewiring methane detector equipment under management supervision so employees could continue to work in these unsafe environments for the purpose of increasing productivity (Christopher, 2010). This eventually led to a destructive situation that lead to injuries, deaths, and a large financial burden.

Allowing employees to work without following safety protocol creates a negative organizational safety culture. If cultures such as the Upper Big Branch Mine are sustained for an extended period, disasters are almost inevitable (Agnew \& Daniels, 2010). On the other hand, a positive safety culture can help prevent work-related injuries, including major disasters similar to what occurred at the Upper Big Branch Mine.

Geller and colleagues (Geller, 2005; Hickman \& Geller, 2003; Ludwig \& Geller, 2000) have empirically examined what entails a positive safety culture. According to Geller (2001a), a positive safety culture encompasses a purposeful relationship between management and employees to improve the safety of all workers. This means that an organization should have adequate safety procedures and proper equipment for their employees. Additionally, management should consistently communicate the importance of 
safety. Those who work safely should be rewarded and/or recognized and those who participate in unsafe practices should be penalized (Pidgeon, 1991).

Geller (2001b) proposes thata positive safety culture focuses on preventive measures. When an organization attempts to prevent accidents before they occur, this communicates to all employees that safety is a priority. This suggests that organizations should place an emphasis on safe practices because it is beneficial to the workers, not merely because it is the law. Sulzer-Azaroff, McCann, and Harris (2001) labeled this type of culture "proactive" because the organization places safety as a priority before a negative event occurs or a law is established.

External pressures may force an existing safety culture to adjust (e.g., tragedy, conforming to a new law). Sulzer-Azaroff et al. (2001) labeled this particular culture "reactive" because the organization adjusts their policies after an event has occurred. However, if employees are not motivated to act safely, most policies will not increase safe behaviors on a large scale (Geller, 2001a). Instead, Geller (1994) advocates that employee motivation for safety should come from participation in the safety program, not a bureaucratic process or regulatory policy.

Safety culture is just one of many subcultures of an overall organizational culture. A positive safety culture should be developed within the framework of an organizational culture to help ensure organizational consistency within safety culture programs (Clarke, 1998). Before continuing with a safety culture literature review, it is necessary to understand what organizational culture is in a broader context, and why researchers continue to focus on it. 


\section{Organizational Culture}

Organizational culture comes from the external environment and the integration of an internal framework (Schein, 1990). There are varying definitions of organizational culture. Organizational culture encompasses the central beliefs, values, and assumptions of the organization (Denison, 1996). Alternatively, a more frank definition of organizational culture is, "the way we do things around here." Schein's (1990) commonly held definition of culture is:

[A] pattern of basic assumptions, invented, discovered, or developed by a given group, as it learns to cope with its problems of external adaptation and internal integration, that has worked well enough to be considered valid and, therefore is to be taught to new members as the correct way to perceive, think, and feel in relation to those problems (p. 111).

Schein's definition should be referred to when organizational culture is referred to in the current study.

Most organizations have mission statements, which should be a reference for appropriate conduct for employees. Cultural assumptions and values are typically the basis of an organization's mission. Yet, this is not always the case. For example, the mission statement for Massey Energy Company, which owned and operated the Upper Big Branch Mine, is currently:

Customers: To supply our customers with the highest quality coals at reasonable and competitive prices.

Shareholders: To earn optimal rates of return on the capital used in our business. Employees: To provide for the best possible well-being of members. 
Communities: To be responsible citizens and responsive to the needs of our environment. (http://www.masseyenergyco.com).

Preliminary evidence from the investigation into the mine disaster suggests that these principles stated in the company's mission were not applied consistently at the Upper Big Branch Mine (Berkes \& Langfitt, 2010; Christopher, 2010). Obviously, the organization's mission and values cannot create or change a culture alone. Supplementary intervention directed at the individual level may be necessary (Redmon \& Mason, 2001).

Kotter and Heskett (1992) suggest that stronger cultures can affect the bottom line and productivity of an organization in three ways. When goals of management and employees are united, each understands why their work is vital and necessary to the organization. Thus, strong communication, both from management to employees and vice versa, is vital. Secondly, the motivation of employees, recently referred to as "engagement" (Bakker \& Schaufeli, 2008), can favorably impact business outcomes (Harter, Schmidt, \& Hayes, 2002). Lastly, strong cultures enhance performance by supplying structure and control without the need of an overbearing establishment of rules and other formalities. These components can contribute to additional organizational profitability within a positive safety culture by reducing injuries and the related costs.

Employee surveys are used to examine organizational culture. In a recent review, Jung et al. (2009) identified 70 instruments for measuring organizational culture. These surveys measure employee attitudes and perceptions across different dimensions of the culture. Twenty-six major dimensions (e.g. ethics, rewards, development, leadership, goals) were identified within those instruments. Organizations who monitor and effectively intervene upon their culture generally improve the work environment for their employees. In 
safety, increasing employee perceptions of their safety culture may be associated with similar positive benefits in terms of reduced injuries and associated costs. Likewise, there are negative consequences involved in a non-existent or poorly structured safety culture.

\section{Safety Culture}

Safety culture, like organizational culture, does not have a universal definition. Lee and Harrison (2000) define safety culture as the values, attitudes, beliefs, risk-perceptions, and behaviors as they relate to employee safety. The Health and Safety Executive of the United Kingdom defined it as:

The safety culture of an organisation is the product of individual and group values, attitudes, perceptions, competencies and patterns of behavior that determine the commitment to, and the style and proficiency of, an organisation's health and safety management... Organisations with a positive safety culture are characterized by communications founded on mutual trust, by shared perceptions of the importance of safety and by confidence in the efficacy of preventive measures (as cited in Gadd \& Collins, 2002, p. 2).

Guldenmund (2000) proposes that safety culture is "[the] aspects of the organizational culture which will impact on attitudes and behavior related to increasing or decreasing risk" (p. 251). For the purposes of this research, Guldenmund's definition of safety culture, based on Schein's (1990) organizational culture definition, will be used.

Safety culture constructs. Two recent reviews of safety culture investigated numerous safety culture surveys, and identified the common constructs measured between the surveys (Flin et al., 2000; Guldenmund, 2000). Based on these and additional research reviews conducted in this study, other factors were found that might also represent core 
factors of safety culture. A list of potential constructs associated with the measurement of safety culture were predicted to be:

- $\quad$ Management Concern

- $\quad$ Personal Responsibility

- $\quad$ Peer Support for Safety

- $\quad$ Safety Management Systems

The following sections provide an overview of these constructs. Some of these core constructs contain sub-constructs which will also be discussed leading up to the reasoning behind a hierarchical factor analysis to ultimately clarify which factors contribute unique variance to safety culture.

Management concern for safety. The most prevalent construct identified in every survey reviewed was the perception of management/supervisors' attitudes and behaviors around safety (Flin et al., 2000). This includes management consideration of employee safety, care for employees, and enforcing safety policies and regulations within their respective business and industry. Dollard and Bakker (2010) found evidence that positive safety culture values can permeate an organization if top management leads safety efforts by communicating and exhibiting the importance of safety. Branham (2010) suggested leadership (management and supervisors) should spend more time on the floor with employees, much like football coaches are on the field with their players.

Level of management. In many safety culture surveys, it is not clear whether employees were reacting to senior executives or their direct supervisors when answering the questions about management (Flin et al., 2000). To clarify this ambiguity, safety culture surveys should distinguish between the individual's supervisor and senior management. 
Questions in the current survey do specifically distinguish between senior management and supervisors. Survey questions around management concern for safety ask employees if they perceive safety as a primary concern for senior management, if their supervisor gives corrective feedback at opportune times, or if their supervisor puts production in front of safety.

Work pressure. Work pressure typically included the pace of work and the amount of workload employees usually faced (Janssens, Brett, \& Smith, 1995; Phillips, Cooper, Sutherland, \& Makin, 1993). This belongs as a sub-factor of management concern because management creates the operation and production schedules. Management should encourage safe behavior along with their operation goals, not in lieu of safety performance. The two should not be viewed as mutually exclusive. Otherwise, employees view production and performance as a higher priority than safety, and unsafe behavior may be reinforced and repeated.

Personal responsibility for safety. Harvey, Erdos, Bolam, Cox, Kennedy, and Gregory (2002) defined personal responsibility as the "perceived responsibility for involvement in safety issues" (p. 23). Harvey et al. found that workers tend to feel less responsibility than managers/supervisors. Perhaps because of this, Guldenmund (2000) gave little attention to the construct. However, personal responsibility does appear in surveys by Cox and Cox (1991) and Coyle, Sleeman, and Adams (1995). Personal responsibility means workers are accountable for their own safety, and management is accountable for reducing their workers' risky behavior, as is part of their job description.

An aspect of personal responsibility that has gained a lot of attention in the literature is risk taking. Risk is possibly the broadest of the constructs assessed through many 
measures such as self-reports of risk taking (Alexander, Cox, \& Cheyne, 1995; Lee, 1998; Mearns, Flin, Fleming, \& Gordon, 1997; Phillips et al., 1993), perception of risk (Brown \& Holmes, 1986), and attitudes toward levels of risk taking (Diaz \& Cabrera, 1997; Janssens et al., 1995; Zohar, 1980). In theory, if organizations work to reduce worker risk taking, this in turn should reduce unsafe practices. The current study assessed risk taking within the personal responsibility factor (e.g., "I tend to work more risky when supervisors are not present"). Survey questions around personal responsibility for safety would ask employees if they bypass safe procedures for means of increasing, production or if they report minor injuries.

Peer support for safety. Outside of measures of management concern, a "caring" factor was not found within any survey reviewed by Flin et al. (2000) or Guldenmund (2000). However, co-workers are constantly around each other while completing job tasks (some of which may be dangerous and hazardous). Therefore, a construct of employee caring seems to be an important safety culture construct related to moment-to-moment safety behaviors.

There is a robust model of employee-focused caring in safety culture literature. For over two decades, Geller (1991, 1994, 2001a, 2001b) has been advocating an Actively Caring factor as an essential part of safety culture. Geller (1991) originally coined the term, Actively Caring, as "employees acting to optimize the safety of other employees" (p. 607). Geller (2001b) suggests Actively Caring occurs when employees go out of their way to alert a co-worker who is exhibiting at-risk behavior or congratulating employees for performing their task safely. He described Actively Caring as positive behaviors that lead to a safer working environment through selection by consequences (2001b). That is, safe behavior is 
reinforced through positive consequences (e.g., a caring social interaction) that occur after a particular action (Skinner, 1981).

In addition to the workers receiving feedback on their safe behaviors, workers who give feedback are also reinforced for "optimiz[ing] the safety of other employees" (Geller, 1991, p. 607). Actively Caring is further discussed in Roberts and Geller (1995) and Geller (1991, 1994, 2001a, 2001b). Throughout the rest of this study, Actively Caring will be referenced as peer support for safety. Survey questions around peer support for safety ask employees if they should caution each other about hazardous work, do caution each other, and respectfully acknowledge each other when they witness a particularly safe behavior.

Safety management system (SMS). "Safety systems" was another construct appearing in the Flin et al. (2000) review. Safety systems include the processes managers in organizations use to control safety. These methods include actions such as designating safety officials (Phillips et al., 1993; Zohar, 1980), creating safety committees (Ostrom, Wilhelmsen, \& Kaplan, 1993; Zohar, 1980), enacting policies (Diaz \& Cabrera, 1997), or developing prevention strategies (Diaz \& Cabrera, 1997). Hahn and Murphy (2008) also argued that perceived worker involvement in safety programs and safety feedback should be included in definitions of safety systems.

Despite the prevalence of the construct in the literature, safety systems were not consistently defined in the previous reviews (Flin et al., 2000; Guldnemund, 2000). Nor were the components measured reliably in past surveys (Fernández-Muñiz, Montes-Peón, \& Vázquez-Ordás, 2007; Hale, 2003; Hale, Heming, Carthey, \& Kirwan, 1997). Thus, a more refined concept of SMS offers a consistent definition and assessment (Fernández-Muñiz et al., 2007; Hale, 2003). While Flin et al. (2000) went as far to say SMS may not be necessary 
when assessing safety culture, others have demonstrated SMS scales can improve the measurement of an overall safety culture if the SMS is well-organized and defined (Bottani, Monica, \& Vignali, 2009; Cooper \& Phillips, 2004).

Fernández-Muñiz et al. (2007) significantly expanded this construct in recent years, suggesting an effective SMS should contain six important aspects: safety policy, incentives for employee participation, training, communication, planning, and control. FernándezMuñiz et al. included a separate factor of employee involvement. However, their study still did not include all core constructs of an SMS or safety culture as described by the current study. According to the current research, all of these factors could be regarded as sub-factors in a SMS:

- Safety Policy, Procedures, and Rules

- Training

- Communication

- Incident Reporting and Analysis

- Safety Audits and Inspections

- Rewards and Recognition

- Employee Engagement

- Safety Meetings/Committees

- Suggestions/Concerns

- Discipline

Safety policy, procedures and rules. Guldenmund (2000) found procedures/rules to be a prominent factor in the studies reviewed (Lee, 1998; Mearns et al., 1997; Ostrom et al., 1993). This construct is defined by employee perceptions of the frequency which they 
comply or violate rules and procedures. Although Flin et al. (2000) suggested this construct is related to risk taking because risk involves breaking rules and not following safety policy, the majority of studies suggested categorizing it under SMS (Fernández-Muñiz et al., 2007; Hale, 2003).

Training. In this research, training was defined as a program that includes all necessary safety information, adequate practice, and consistency. In a more recent metaanalysis, Christian, Bradley, Wallace, and Burke (2009) found that selecting and training safe workers can increase dispositional factors related to safety culture (e.g. safety knowledge, safety motivation). This, in turn, can aid in decreasing the number of accidents and injuries within the workforce. Safety specific training also demonstrates the company places a priority on safe work practices (Christian et al., 2009).

Communication. Hale, Guldenmund, van Loenhout, and Oh (2010) emphasize that components of the SMS need to be consistently communicated and applied from top management and safety professionals. Top-down communication is necessary to show midmanagement and frontline workers that a proper safety initiative is vital for organizational success (Dollard \& Bakker, 2010). Examples of communication found in the current research include regular communication of safety goals from management to employees and certainty that incident reports are regularly reviewed and shared with employees.

Incident reporting and analysis. The findings of Nielsen, Carstensen, and Rasmussen (2006) suggest reporting minor injuries and near-misses are associated with decreased longterm injuries. Computer-based or traditional paper-based reporting procedures can be used to track these reports. Nielsen et al. advocate that employees should not only report minor or near incidents, but they should also have an opportunity to offer suggestions for future 
preventive measures. Incident reporting and analysis may also be related to both management concern and employee involvement; however, most suggest it is primarily a SMS factor (Nielsen et al.).

Safety audits and inspections. Kunreuther, McNulty, and Kang, (2002) emphasize the importance of proper inspections and audits in a safety management plan. This element of an SMS can be particularly costly, so Kunreuther et al. suggest using a third party to coordinate inspections instead of hiring or using current employees who may have biases. Branham (2010) calls audits "forced compliance," but in the current study audits and inspections consist of offering regular safety feedback from inspections, and prioritizing hazards according to potential for injury.

Rewards and recognition. Rewards and recognition are important for safety management systems if they adequately reinforce safe behavior while punishing at-risk behavior (Hsu, Lee, Wu, \& Takano, 2008; Pidgeon, 1991). Rewards and recognition were defined as a fair incentive and feedback system that encourages employees to work safely. A fair system includes not rewarding employees who fail to work in accordance with safe procedures (Hsu et al., 2008). An example of rewards and recognition comprises of employees who work safe then benefit from better performance reviews, and those who are not safe do not get the same recognition. Another example is the celebration of safety achievements in work units. However, the recognition of safety milestones is only productive if it does not inhibit incident reporting. Geller (2000) suggests celebrating milestones such as a specific number of incident reports or safety audits.

Employee engagement. Dollard and Bakker (2010) suggest that employee engagement in safety at work can lead to positive organizational outcomes, such as fewer 
work-related injuries, if employees have adequate resources. It is empowering for employees to be involved in their work processes and associated safety processes (Hsu et al., 2008). Branham (2010) suggests a workforce is engaged when individuals promote safe behaviors and actively reduce workplace hazards. Interestingly, safety culture is more correlated with worker engagement than worker compliance with rules and procedures (Christian et al., 2009). As such, Podgórski (2006) suggests that a good SMS has a mechanism for employee engagement. Survey questions around engagement would include asking employees if they correct safety hazards without being told, even if it temporarily prohibits production.

Safety meetings/committees. Hale et al. (2010) stress the importance of having a vehicle whereby workers and management can discuss and solve safety issues. Christian et al. (2009) suggest one way safety information can be communicated is formally through meetings. This can be achieved through open employee participation or through representatives voted on by employees (Podgórski, 2006). Washington State requires all large organizations to construct safety committees under certain conditions and suggests smaller operations conduct regular safety meetings (Washington State Department of Labor and Industries, 2009). Within these regulations, safety meetings/committees were required to be held monthly, and a manager representative was required to be present. Examples of topics discussed in these meetings included reviewing safety/health inspection reports to correct safety hazards, evaluating accident investigations conducted to determine if the causes of the safety hazard were identified and corrected, evaluating workplace accident and illness prevention program and discussing suggestions for improvement. These guidelines around safety meetings are constructive for the successful implementation of a positive safety culture (Podgórski, 2006) and should be assessed in safety culture assessments. 
Suggestions/concerns. An additional way employees can express safety issues and concerns is a mechanism for employee suggestions. This construct was defined as employees offering appropriate suggestions, and supervisors acting swiftly and appropriately in the response. Tharaldsen, Mearns, and Knudsen (2010) suggest a system for employees to recommend improvements in safety procedures to managers (bottom-up communication). However, suggestions need to be taken seriously, or else employees could view the process as a joke (McAdam, 2011). Some organizations that have saved money due to employee suggestions offer a monetary award to the employee who made the recommendation (McAdam, 2011).

Discipline. Disciplinary actions should be consistent, fair, and appropriate when atrisk behaviors are found whether an injury occurs or not. Branham (2010) suggests it is best to avoid discipline when an alternate learning opportunity is available, because discipline never immediately follows the unsafe behavior. Further, he suggests discipline should be used constructively to encourage workers, not merely to discourage particular behaviors. Survey question examples may include asking if employees are disciplined when they should be and if discipline for violations is fair and consistent.

Summary of safety culture survey constructs. Some constructs reviewed above have never been included in a published survey of safety culture but have potential to offer meaningful value to safety culture measurement. The most common factor in any review involved management concern, so this was included in the current research as management concern for safety. A personal responsibility factor was sparse in the literature review. However, employees should be responsible for their own safety and amount of risk taking within their organization (Harvey et al., 2002). Therefore, a second factor to be included was 
personal responsibility for safety. Actively Caring has not received any attention in surveys but has been argued for (Geller, 2001a); so in this study Actively Caring was included as peer support for safety. Finally, SMS has not been included in a safety culture survey as extensively as the above review suggests it should. Thus, this study suggested several constructs that should be included as sub-factors of a safety management system.

\section{Safety Culture Survey and Factors}

Safety culture, like organizational culture, is measured by surveying employee attitudes and perceptions of the organization, its management, and their own actions regarding safety. There have been numerous attempts at developing safety culture surveys. Guldenmund (2000, pp. 230-234) and Flin et al. (2000, pp. 181-184) have each presented extensive tables which facilitate the understanding of many surveys and the aforementioned constructs. Flin et al. focused on common constructs of safety culture surveys while Guldenmund primarily reviewed the many theories and models of safety cultures. Each provided detailed information about the surveys (e.g. number of questions, factors measured). However, it is difficult to find a single survey that exhibited any predictive quality in actual safety performance or statistics. Surveys should reflect predictive qualities if they are to be useful. Nevertheless, until a full meta-analysis is conducted, what accurately predicts a good safety culture is not easily discerned (Flin et al. 2000).

The safety culture factor analysis in this study aims to clarify core factors that should be included in safety culture measurements but have not been reviewed thoroughly in the survey literature. The individual factors included in the factor analysis were chosen because they appeared in a majority of safety culture surveys as reviewed by Flin et al. (2000) or Guldenmund (2000). However, gaps seemed to be prevalent in previous safety culture 
survey literature. One gap was peer support for safety, which was left out entirely, and the other was safety management systems, which appeared in the literature but was expanded in this study. Therefore, these new and expanded factors were also investigated.

"Safety Culture" was indicated by four related but distinct constructs: management concern, personal responsibility for safety, peer support for safety, and safety management systems with a number of sub-factors according to the previous review. Therefore, Safety Culture was a higher-order latent variable that shaped these characteristics, as shown in Figure 1. Moreover, sub-factors may be safety culture variables that were likely to be highly correlated, which would be consistent with Edwards and Bagozzi (2000). Based on the literature review, Figure 1 presents potential major constructs that should be included in a survey measuring safety culture.

The factor structure was considered as a reflective construct with effects indicators flowing from the construct to the individual factors (see Figure 1) rather than a formative construct. Simply stated, the safety culture causes the items of the survey to reflect the changes in the overall construct. This is the typical structure when considering the development of a survey.

This study further investigated the safety culture construct through both an exploratory and hierarchical confirmatory factor analysis. An exploratory factor analysis was conducted to determine which questions contributed meaningful value to the model. A hierarchical confirmatory factor analysis was conducted to validate the results of the exploratory analysis and to determine the hierarchical structure proposed by the current model. There were two hypotheses. We expected the proposed core factors, as well as the structure of those factors above, to represent a more complete safety culture as compared to 
previous surveys in the literature. The second was that the survey items would be reduced to those that add meaningful statistical value to the safety culture survey.

\section{Method}

\section{Participants}

This survey was administered by means of online and paper formats to 25,574 employees across five multinational companies representing five different industries. The industries represented included mining, chemical, healthcare, steel, agricultural. Countries representing all contents with the exception of Antarctica were included in this study. This study was approved by Appalachian State University’s Institutional Review Board (\#110189, see Appendix A).

\section{Survey Development}

Seven Subject Matter Experts (SME) in safety culture with extensive professional experience as safety consultants were used for question development. Each SME held a graduate (masters or doctoral level) degree in industrial/organizational psychology, industrial engineering, human factors engineering/ergonomics, organizational design and development, occupational safety and health, communications, and/or education/training.

The Q-Sort method (Van Exel \& de Graff, 2005) is the technique used to construct questions of a safety culture survey. First, an analysis of the reviewed literature was evaluated by the SME. Then, each SME prioritized the constructs, which revealed the importance of each construct. Next, each prioritized list was examined to show which constructs were most important in contributing to a safety culture survey according to all of the SME judgments. Once the factors were constructed, a set of questions was created for each factor. These questions underwent various stages of sorting between the SME to 
determine what was necessary in measuring a safety culture construct and what was irrelevant or redundant. Once a consensus was made, the questions were assembled into a survey.

The SMEs developed 92 questions (see Appendix $B$ ) which are tentatively organized into four broad scales: a) management concern for safety (16 questions), b) peer support for safety (10 questions), c) personal responsibility for safety (7 questions), and d) safety management systems (54 questions). There were numerous questions that overlapped between scales, along with five questions that did not reliably fall into a potential scale but were considered important enough to keep in the survey. There were 12 items that were reverse-scored because the meaning of the questions were the opposite direction of the scale (i.e., high-rated items were considered negative responses, and low-rated items were considered positive responses). Lastly, all items were rated on the same 5-point Likert scale (e.g., "Strongly Disagree - Disagree - Neutral - Agree - Strongly Agree”).

\section{Results}

\section{Descriptive Statistics}

The dataset consisted of 25,574 participants from five multinational organizations within five different industries. Appendix $B$ presents the means, medians, standard deviations, variances, skewness, standard error of the skewness, kurtosis, and standard error of kurtosis for each item in the survey. Although most items were negatively skewed, normality is not an assumption of factor analysis (Tabachnick \& Fidell, 2007). The overall reliability estimate (Cronbach's alpha) for the survey was $\alpha=.95$. 


\section{Exploratory Factor Analysis (EFA)}

After initial descriptive analyses were conducted, the 92-item measure was subjected to an EFA to assess the number of safety culture factors using approximately half of the study's participants, 12,709 workers (Cudeck \& Browne, 1983). This selection procedure was completed at random. The EFA was performed using SPSS for Windows, Release Version 18.0, (SPSS, Inc., 2009). The EFA used principal component analysis as an extraction method with direct oblimin rotation (Fabrigar, Wegener, MacCallum, \& Strahan, 1999) on the randomly selected first half of the data set (Cudeck \& Browne, 1983).

To determine the maximum number of factors that should be interpreted, the Kaiser rule was utilized (Fabrigar et al., 1999). Therefore, all factors with an eigenvalue above 1.0 were held for the hierarchical confirmatory factor analysis. The results can be found in Table 1. Originally, the results indicated that 13 factors should be retained for interpretation. However, the original fifth factor held three items, two of which were Heywood cases (i.e., correlations over 1 or below negative 1) and the other was a cross-loaded item.

Consequently, this factor was removed from the analyses. Table 1 also indicates over $50 \%$ of the safety culture model can be explained by these 12 factors.

The resultant names of the resultant 12 factors are presented in Table 2 and the factor loadings are presented in Table 3. (Note that the item numbers shown in Table 3 correspond to the items written in full in Appendix B.) The theoretical factors of management concern, personal responsibility for safety, peer support for safety, and safety management systems are reflected relatively evenly throughout the 12 factors. Factors 3 and 12 were indicated only by reverse-scored items, an occasional problem noted in past EFA research by Fabrigar et al. 
(1999) and Hinkin (1995), but both rationally contributed to the model. Therefore, they were not discarded.

Using Tabachnick and Fidell's (2007) recommendation of .33 as a minimum cutoff for a factor loading, 13 items were removed for insufficiently loading on any factor. Another four items were removed for cross-loading on multiple factors or because they were Heywood cases, as mentioned previously. Finally, three items were dropped because there was no rational basis to include them on the factors in which they loaded.

At the conclusion of this process, 72 items were retained representing the aforementioned 12 factors. This set of 72 items demonstrated good reliability $(\alpha=.93)$. Correlations among the four sub-factors of safety culture including management concern for safety, personal responsibility for safety, peer support for safety, and safety management systems were significant and strong (see Table 4). As expected, there were higher correlations between dimensions representing conceptually similar dimensions (i.e., management concern for safety, peer support for safety, and safety management systems). Also expected was an artifactual reverse-scoring issue that arose with the personal responsibility for safety factor, which decreased both the correlations with the other factors as well as internal reliability of the personal responsibility factor consistent with Harvey et al., (1985). Generally, though, reliability estimates were high for each of the four sub-factors of safety culture: $\alpha=0.88$ for management concern for safety, $\alpha=0.68$ for personal responsibility for safety, $\alpha=0.84$ for peer support for safety, and $\alpha=0.94$ for safety management systems. These factors were then tested using a hierarchical factor structure procedure to determine the accuracy of the presented model. 


\section{Hierarchical Confirmatory Factor analysis (HCFA)}

After the exploratory analysis was completed, the other half of the randomly selected participants, 12,865 respondents, was examined using HCFA using Mplus 4.21 (Muthén \& Muthén, 2002). This was conducted to determine if the conclusions of the EFA were reliable.

A HCFA was conducted to cross-validate the four-factor structure that emerged from the literature review. MPLUS 4.21 (Muthén \& Muthén, 2002) was employed to confirm the hypothesized model and the results of the EFA. The safety culture model was a hierarchical model in which the superordinate safety culture construct affects the four first-order constructs.

Before conducting the analyses, it was necessary to parcel the items within the factors consistent with Hall, Snell, and Foust (1999). The items constituting each extracted factor were parceled as unidimensional indicators. The range of items on the parcels varied from two to nine items depending on the factor. Each parcel was combined because of theoretical reasons, and to account for the artifactual reverse-scored items, which fell on two factors. This procedure allowed the HCFA to reveal the nature of the model better than the individual items could because it reduced secondary factor contamination. The rationale used to parcel items was consistent with the recommendations made by Hall et al. (1999).

After the parceling procedure was conducted, the hierarchical model was then specified to estimate each of the loadings on the four second-order factors and the 12 parceled indicators. There was a strong positive correlation $(r=.47, p<.001)$ between indicators 3 and 12, the two artifactual reverse-scored indicators, so this was specified to further identify the model. 
The hierarchical model from the literature view was confirmed through HCFA. Table 5 demonstrates the model produces good fit. A comparative fit index (CFI), which was expected to be close to 0.95 or greater (Hu \& Bentler, 1999), was $\mathrm{CFI}=0.95$. A root mean square error of approximation (RMSEA), which was expected to be close to 0.06 or lower (Hu \& Bentler), was RMSEA = 0.08. A standardized-root-mean-square residual (SRMR), which was expected to be close to 0.08 or lower $(\mathrm{Hu} \&$ Bentler), was SRMR $=0.04$. The chi-square difference test is hypersensitive to very large or small sample sizes, and can falsely indicate poor model fit (Tabachnick \& Fidell, 2007). Consequently, because the sample size in this study was very large, it was not considered as a fit index in the analysis. Consistent with Kline (2005), the fit indices indicate a good fit to the data. There was a strong theoretical reason to expect a hierarchical structure. Therefore, these results were supportive of the theoretical model. Figure 2 shows the results of this model with all factorloading coefficients. Further, Table 6 shows the factors, which the SME thought each item should originate, and where each item was placed after the empirical analyses.

\section{Discussion}

The literature review of safety culture constructs and measurement determined that not all constructs that frame a safety culture had been included in safety culture surveys. Namely, factors of personal responsibility for safety and safety management systems had not been thoroughly examined in safety culture measurements, while peer support for safety had not been examined in any reviewed survey. Thus, the purpose of this study was to determine a complete set of core factors for measuring a safety culture and to reduce the survey to a rational set of items that contributes meaningful variance to the measurement of safety culture. 
The results presented empirical support for the proposed model. This evidence indicated that the factor structure of the safety culture survey was empirically validated after the initial expert (SME) survey development process. Therefore, this measure already exhibited content validity measuring all core areas reviewed in the literature (Flin et al., 2000; Geller, 2001a; Guldenmund, 2000). Figure 2 shows the core factors extracted from this study and demonstrates the hierarchical structure determined by the HCFA.

\section{The Model}

The theoretical model from the literature review was confirmed, with some exceptions. First, not all reviewed factors were extracted in the initial EFA. Second, two of the sub-factors, personal responsibility for safety and peer support for safety, were determined to have a more complicated hierarchical factor structure according to the HCFA than was originally hypothesized. Conversely, the SMS factor was determined to be less complicated than hypothesized. However, because the factor loadings were so robust (see Figure 2), it is reasonable to assume that the overall model was supported, and safety culture consists of the aforementioned factors.

The overall model indicated good fit (see Table 5). The CFI and the SRMR fell within range of good fit as indicated by $\mathrm{Hu}$ and Bentler (1999). The RMSEA fell within the close or acceptable range as indicated by $\mathrm{Hu}$ and Bentler (1999) and Fan and Sivo (2007). Additionally, $50 \%$ of the variance of a safety culture is explained in this model (see Table 2).

The safety model presented in Figure 2 illustrates safety culture as a second-order latent variable, and management concern for safety, personal responsibility for safety, peer support for safety, and safety management systems as first-order sub-factors, as identified by 
12 parceled indicators. The following is a summary of the factors extracted through the two analyses.

First, management concern for safety was determined to be consistent with the literature review (Flin et al., 2000). The review suggested safety culture surveys should distinguish between different levels of management. The EFA extracted separate "supervisor concern" and "senior management concern" factors, and the HCFA confirmed they should be sub-factors of management concern for safety. A third factor of "work pressure" was proposed to fall under management concern because supervisors and management control production and operation schedules. This factor was also extracted from the EFA and confirmed by the HCFA.

Second, personal responsibility for safety was determined to have three sub-factors. This is not what the hypothesized model proposed, but the factors fell rationally under the personal responsibility factor nonetheless. In the review, risk taking was the main factor of personal responsibility, and this was confirmed in the HCFA. Risk taking was one of the two reverse coded parcel factors. Therefore, there was a negative, although still strong, factorloading. The other reverse coded factor was "supervisor and management blame." This was not reviewed as a separate factor under personal responsibility, but it is rational to put it under this responsibility factor. If supervisors and management blame the employee before an investigation or without looking at the overall situation, this is unconstructive and not a responsible way to supervise employees. This factor did not fall under the management concern, or safety management systems factor because of the wording of the items. Once again, there was a strong negative factor-loading as shown in Figure 2. The third factor was "incident reporting." This factor was reviewed under SMS, but the factor extracted in the 
EFA was most reasonably included under personal responsibility because it assesses the frequency of reporting incidents and near misses. It is the employees' responsibility to report incidents when they should.

Peer support for safety was not hypothesized to include sub-factors. However, two related but distinct, peer support factors were extracted from the EFA. The two factors are "cautioning others" and "respectful feedback." Each of these factors is rationally included under peer support for safety, and this was confirmed by the HCFA. "Cautioning others" assesses whether workers will intentionally disrupt their production to assist a co-worker working at risk. "Respectful feedback" assesses whether they offer feedback to others and do so respectfully.

Lastly, safety management systems was determined to be much less complex than the literature review suggested. Instead of the hypothesized 10 factors, four were extracted from the EFA and then confirmed by the HCFA. The four factors were "communication," "training and rules," "discipline and investigation," and "rewards and recognition." "Training and rules" were combined in a factor extracted from the EFA, and this is reasonable because workers can learn the safety rules through training (Christian et al., 2009). The EFA did not extract any factors of safety audits and inspections, employee engagement, safety meetings/committees, or suggestions/concerns. Additionally, the “incident report" factor fell under personal responsibility better than safety management systems because the individual is responsible for reporting his or her own incidents. Otherwise, "communication," "discipline and investigation," and "rewards and recognition" are rationally included under SMS as the literature review suggested. 
Overall, this model is very consistent with the constructs and factors listed in the literature review (Flin et al., 2000; Geller, 2001a; Guldenmund, 2000). Some were expanded and others were removed, but the HCFA confirmed the rationality of the overall model. The survey, based on the model, accurately assessed safety culture according to these results. Thus, the proposed model addressed certain gaps in the literature, and statistical analyses confirmed the rationale behind the model.

\section{Gaps Addressed in Current Model}

This study suggests the four factors of management concern for safety, personal responsibility for safety, peer support for safety, and safety management systems. By including all four factors, this study addresses a gap in the literature. Not all safety culture surveys have incorporated the necessary core safety culture factors as proposed by the current research. For example, no surveys previously reviewed incorporated any peer support for safety. Thus, this study expanded on a key gap in the literature by including this factor. Second, a full personal responsibility for safety factor was not thoroughly constructed in the literature (Cox \& Cox, 1991; Coyle, Sleeman, \& Adams 1995; Harvey et al., 2002), although risk taking is prominent in many safety culture surveys (Flin et al., 2000).

Lastly, some have suggested, a systems or SMS factor is not necessary in assessment of safety culture (Flin et al., 2000). However, others confirmed that this factor was not only necessary, but an essential part of evaluating safety culture (Fernández-Muñiz et al. 2007; Hale, 2003). Fernández-Muñiz et al. had come closest to fully reviewing the proposed model of SMS, but still omitted important components of the construct. However, the proposed model was not entirely confirmed, as "training and rules," "communication," "discipline and investigation," and "rewards and recognition" were the only extracted factors found on safety 
management systems. As previously suggested, the other factors were not extracted in the EFA, or they rationally fell on a separate factor (i.e., personal responsibility for safety). Whether the factor fell on a safety management system or personal responsibility for safety factor depended on the wording of the items.

An organization can have a more thorough understanding of their safety culture by utilizing a survey, which includes the four core factors as found in the current study. By addressing these gaps, this survey may provide the ability for organizations to better assess their safety culture, intervene where necessary, and in doing so, yield important financial results.

\section{Implications}

Once an organization has a systematic understanding of their safety culture, they can understand the financial benefits and other business outcomes from safety interventions and programs. For example, management concern is necessary when creating a safety culture, but a lack of management involvement can have some negative financial implications. Smallman and John (2001) conducted a thorough analysis of senior management in Financial Times and Stock Exchange (FTSE) UK index companies and found they all viewed safety as a priority. They collectively agreed that a poor safety record could negatively impact stakeholders' views of the organization and damage the company financially. Conversely, it was also noted, that an excellent safety record did not always translate to financial success. Perhaps, organizations with better safety records are not always enhanced financially, but those with poor safety records have little opportunity for stakeholder and investor support. It is possible for organizations to over-invest in safety. In doing so, they may have an excellent 
safety record, but their overall profit margins may decrease. An efficient way to increase safety in the workplace is to increase co-worker support.

Peer support for safety has the most empirical support for financial returns. When Turner, Hershcovis, Chmiel, and Walls (2010) evaluated three levels of organizational support (i.e., senior management, supervisors, and co-workers), co-workers were the most important for increasing worker safety in hazardous situations. The study showed that with increased co-worker support, there were decreased injuries translating into lower financial expenditures for the organization. If workers constantly monitor each other and offer corrective and positive feedback, that supportive behavior can increase the enhancement of a safety culture (Geller, 2001a). However, if an organization does not have the system and incentives in place to achieve this culture, the supportive behavior may not be sustained.

As recommended in the literature review, quality organizational SMS programs are necessary for a supportive safety culture. Financial benefits can be sustained when the SMS is consistent with safety and organizational goals. Accordingly, organizations who implement a good SMS show superior business results and performance in safety outcomes against companies who do not have a well-organized SMS (Bottani, 2009). Podgórski (2006) also suggests investment in a quality well-implemented SMS should provide the organization with financial success. While a poor system that is not consistent with organizational goals may enhance safety performance, it may not necessarily increase financial results (Podgórski, 2006).

One of the more interesting implications is the cumulative effects of the proposed model. Cox, Jones, and Collinson (2006) have demonstrated that trust (i.e., management concern for safety), accountability (i.e., personal responsibility for safety), and caring (i.e., 
peer support for safety) can have an economic benefit to organizations and their stakeholders. Their study found that organizations who exhibit high trust could have a substantial increase to the bottom line. Those with a lower level of trust show a negative economic impact on their respective businesses. Thus, when the entire proposed model is implemented efficiently and effectively, considerable business outcomes can be achieved.

\section{Strengths}

This study consisted of some important strengths. The main strength involved the breadth and number participants. Thousands of workers completed the survey from multiple locations of multinational corporations. These corporations were from five different industries and had varying safety records. Thus, the data were far from a homogenous response set and should generalize quite well. Another strength of this study was how well the theorized expert model from the review matched the EFA and HCFA results. The theorized and empirical models are not identical, but the factor loadings confirmed the model was quite robust. However, further research is necessary to demonstrate empirical validation of this safety culture survey.

\section{Future Directions}

The current research confirmed the theoretical model of safety culture, but more research should be conducted for further validation of the survey. Criterion and construct validation should be conducted in future studies. Measurement of safety culture attitudes is important, but prediction of safety performance would be ideal. Therefore, criterion validation is one avenue for future research.

Criterion validity. Criterion validity assesses the predictive qualities from a measure to some outcome or performance (Cronbach \& Meehl, 1955). Concurrent and predictive 
validity research could offer validation of this survey. Concurrent validity could be assessed by comparing the overall scores from the measure with current safety performance statistics (e.g., minor injuries, near misses, lost workdays). Predictive validity could be assessed by examining the scores from the survey at one point and comparing those scores with the safety performance from a future date. If a predictive link is empirically supported from this safety culture survey to safety performance, the value of the measurement will surely increase.

Although few studies have presented a connection between safety performance statistics and culture measurement surveys, Cooper and Phillips (2004) suggest once enough data is compiled, a relationship should be noticeable. However, they do recognize that changes in safety culture measures may not lead to improvements in performance and vice versa.

Construct validity. Construct validity could also be examined in future research. Construct validity determines if a measure truly measures the theoretical construct it claims to assess (Cronbach \& Meehl, 1955). This would involve determining convergent and discriminant validity. For convergent validity, the safety culture survey should theoretically correlate with other measures of safety culture. While divergent validity would determine if the safety culture survey did not correlate with other measures, such as Scholastic Assessment Test (SAT) scores, which it theoretically should not.

\section{Limitations}

There is potential for new safety culture research to contribute to the literature in a wide variety of organizations, and the findings suggest that the safety culture survey is a useful tool for future research. However, this study does have several limitations that need to be acknowledged. 
As with all measurements of safety culture, this survey can only measure the attitudes and perceptions of workers about the priority of safety in their organization. As previously mentioned, there is not a consensus on whether measuring safety culture can improve or predict actual safety performance (Cooper \& Phillips, 2004; Glendon \& Litherland, 2001). Future research could produce this criterion-related validation.

Another limitation was the 12 artifactual reverse-scored items. Although it was rational to include the factors in the model, the reliability and inter-item correlations decreased with the frequency of reverse-scored items as was consistent with Harvey et al. (1985). Nevertheless, the model still exhibited robust results in both factor-loadings and overall reliability.

Alternate models could have also been useful in further determining the structure of safety culture. Specifically, safety culture could simply be a first-order factor with the 12 parcel indicators reflecting from the factor. Other models could increase the low reliabilities and intercorrelations which were observed in the personal responsibility factor. This is another possible opportunity for future research.

Lastly, Hu and Bentler (1999) suggested the RMSEA should be .06 or less to be indicative of good model fit. However, the RMSEA was determined to be 0.08 in this study. This is still within an acceptable range as poor fit is indicated by an RMSEA of 0.10 or higher. Nonetheless, the other fit statistics robustly reproduced the data, so this was not determined to be of great importance.

\section{Summary and Conclusion}

To conclude, this study attempted to evaluate the core factors of a safety culture, including two factors that needed expansion and one factor that seemed to be missing from 
the measurement literature. Safety culture was determined to be a higher-order latent variable, which consisted of four sub-factors (management concern for safety, personal responsibility for safety, peer support for safety, and safety management systems) and 12 total factors loading on the sub-factors. The safety culture survey was reduced from 92 to 72 items, which measure the 12 factors of the higher-order safety culture construct. Further research should examine the predictive ability of the measure for practical use within different organizations.

However, the use of the safety culture survey is not enough to change an unsafe culture into a positive safety culture. Procedural intervention is necessary (Redmon \& Mason, 2001). Fortunately, the current measure attempts to assess the mechanisms that organizations utilize to implement effective safety interventions (e.g., communication, training). Data presented by McSween (2011) suggests when leadership (senior and/or midlevel management) participates in the safety process, there are substantial increases in the sustainability of the program. He does note that this cannot simply be communication, but leadership must do something in a visible way for the employees to observe. Further, DePasquale and Geller (1999) found that organizations who implemented mandatory programs attained more positive organizational results than other organizations who implemented voluntary programs.

The construction of a positive safety culture is not easy, and it is not universal. Something that works well in one organization may not work in another. Adjustments will need to be made depending on the resources available and the goals of the different organizations. No matter what an organization does to increase safety, the workforce needs to be included in the process beyond simply measuring their attitudes. 
It is important to emphasize that measuring employee perceptions of safety culture does show some commitment to safety, but that cannot be the end of the process. It is the start of an enduring process, which requires that senior management makes safety performance a priority in the organization. The results of the measurement must be communicated, and a plan should be implemented to ensure workers that there is precedence for safety performance, not just safety culture measurement (Cooper \& Phillips, 2004). 


\section{References}

Agnew, J. \& Daniels, A. C. (2010). Safe By Accident: Take the Luck Out of Safety: Leadership Practices that Build a Sustainable Safety Culture. Atlanta, GA: Performance Management.

Alexander, M., Cox, S., \& Cheyne, A. (1995, February). The concept of safety culture within a UK offshore organization. In: Collected papers of the 'Understanding Risk Perception" conference. Aberdeen.

Bakker, A. B., \& Schaufeli, W. B. (2008). Positive organizational behavior: Engaged employees in flourishing organizations. Journal of Organizational Behavior, 29, 147154.

Behm, M., Veltri, A., \& Kleinsorge, I. K. (2004). The cost of safety: Cost analysis model helps build business case for safety. Professional Safety, 4, 22-29.

Berkes,H. \& Langfitt, F. (2010, May 17). Mine probe examines airflow, possible tampering. National Public Radio. Retrieved from http://www.npr.org

Bottani, E., Monica, L., \& Vignali, G. (2009). Safety management systems: Performance differences between adopters and non-adopters. Safety Science, 47, 155-162. doi:10.1016/j.ssci.2008.05.001

Branham, C. (2010). The role of discipline in leading safety performance. Management Quarterly, 51, 16-22.

Brown, R., \& Holmes, H. (1986). The use of a factor analytic procedure for assessing the validity of an employee safety climate model. Accident Analysis and Prevention, 18, 445-470. 
Christian, M. S., Bradley, J. C., Wallace, J. C., \& Burke, M. J. (2009). Workplace safety: A meta-analysis of the roles of person and situation factors. Journal of Applied Psychology, 94,1103-1127. doi: 10.1037/a0016172

Christopher, A. (2010, July 14). Upper Big Branch workers deliberately disabled methane monitor months before fatal explosion, miners exclusively tell NPR News. National Public Radio. Retrieved from http://www.npr.org

Clarke, S. (1998). Perceptions of organizational safety: implications for the development of safety culture. Journal of organizational Behavior, 20, 185-198.

Cooper, M. D., \& Phillips, R. A. (2004). Exploratory analysis of the safety climate and safety behavior relationship. Journal of Safety Research, 35, 497-512. doi:10.1016/j.jsr.2004.08.004

Cox, S., \& Cox, T. (1991). The structure of employee attitudes to safety: An European example. Work and Stress, 5, 93-106.

Cox, S., Jones, B., \& Collinson, D. (2006). Trust relations in high-reliability organizations. Risk Analysis, 26, 1123-1138. doi:10.1111/j.1539-6924.2006.00820.x

Coyle, I. R., Sleeman, S. D., \& Adams, N. (1995). Safety climate. Journal of Safety Research, 26, 247-254.

Cronbach, L. J., \& Meehl, P. E. (1955). Construct validity in psychological tests. Psychological Bulletin, 52, 281-302.

Cudeck, R, \& Browne, M. W. (1983). Cross-validation of covariance structures. Multivariate Behavioral Research, 18, 147-167. 
Denison, D. R. (1996). What is the difference between organizational culture and organizational climate? A native's point of on a decade of paradigm wars. Academy of Management Review, 21, 619-654.

DePasquale, J. P., \& Geller, E. S. (1999). Critical success factors for behavior-based safety: A study of twenty industry-wide applications. Journal of Safety Research, 30, 237249.

Diaz, R., \& Cabrera, D. (1997). Safety climate and attitude as evaluation measures of organizational safety. Accident Analysis and Prevention, 29, 643-650.

Dollard, M. F., \& Bakker, A. B. (2010). Psychological safety climate as a precursor to conducive work environments, psychological health problems, and employee engagement. Journal of Occupational and Organizational Psychology, 83, 579-599.

Edwards, J. R., \& Bagozzi, R. P. (2000). On the nature and direction of relationships between constructs and measures. Psychological Methods, 5, 155-174.

Fabrigar, L.R., Wegener, D.T., MacCallum, R.C. \& Strahan, E.J. (1999). Evaluating the use of exploratory factor analysis in psychological research. Psychological Methods , 4, 272-299.

Fan, X., \& Sivo, S. A. (2007). Sensitivity of fit indices to model misspecification and model types. Multivariate Behavioral Research, 42, 509-529.

Fernández-Muñiz, B., Montes-Peón, J. M., \& Vázquez-Ordás, C. J. (2007). Safety culture: Analysis of the causal relationships between its key dimensions . Journal of Safety Research, 38, 627-641.

Flin, R., Mearns, K., O’Connor, P., \& Bryden, R. (2000). Measuring safety climate: identifying the common features. Safety Science, 34, 177-192. 
Gadd, S., \& Collins, A. M. (2002). Safety culture: A review of the literature. Health \& Safety Laboratory. HSL/2002/25.

Geller, E. S. (1991). If only more would actively care [Editorial]. Journal of Applied Behavior Analysis, 24, 607-612.

Geller, E. S. (1994). Ten Principles for achieving a total safety culture. Safety Management, $39,18-24$.

Geller, E. S. (2000, May 19). How to celebrate safety success. Industrial Safety and Hygiene News. Retrieved from http://www.ishn.com

Geller, E. S. (2001a). Actively caring for occupational safety: Extending the performance management paradigm. In C. M. Johnson, W. K. Redmon, \& T. C. Mawhinney (Eds.), Handbook of Organizational Performance: Behavior Analysis and Management (pp. 303-326). Binghamton, NY: Hawthorn Press.

Geller, E. S. (2001b). The Psychology of Safety Handbook. Boca Raton, FL: CRC Press. Geller, E. S. (2005). Behavior-based safety and occupational risk management. Behavior Modification, 29, 539-561.

Glendon, A. I., \& Litherland, D. K. (2001). Safety climate factors, group differences and safety behavior in road construction. Safety Science, 39, 157-188.

Guldenmund, F. W. (2000). The nature of safety culture: A review of theory and research. Safety Science, 34, 215-257.

Hahn, S. E., \& Murphy, L. R. (2008). A short scale for measureing safety climate. Safety Science, 46, 1047-1066.

Hale, A. R. (2003). Safety management in production. Human Factors and Ergonomics in Manufacturing, 13, 185-201. doi:10.1002/hfm.10040 
Hale, A. R., Guldenmund, F. W., van Loenhout, P. L. C. H., \& Oh, J. I. H. (2010). Evaluating safety management and culture interventions to improve safety: Effective intervention strategies. Safety Science, 48, 1026-1035. doi:10.1016/j.ssci.2009.05.006

Hale, A. R., Heming, B. H. R., Carthey, J., \& Kirwan, B. (1997). Modeling of safety management systems. Safety Science, 26, 121-140.

Hall, R. J., Snell, A. F., \& Foust, M. S. (1999). Item parceling strategies in SEM: Investigating the subtle effects of unmodeled secondary constructs. Organizational Research Methods, 2, 233-256.

Harshbarger, D. (2009). Witness at Hawks Nest. Huntington, WV: Mid-Atlantic Highlands. Harter, J. K., Schmidt, F. L., \& Hayes, T. L. (2002). Business-unit level relationship between employee satisfaction, employee engagement, and business outcomes: A metaanalysis. Journal of Applied Psychology, 87, 268-279.

Harvey, R. J., Billings, R. S., \& Nilan, K. J. (1985). Confirmatory factor analysis of the job diagnostic survey: Good news and bad news. Journal of Applied Psychology, 70, 461468.

Harvey, J., Erdos, G., Bolam, H., Cox, M. A. A., Kennedy, J. N. P., \& Gregory, D. (2002) An analysis of safety culture attitudes in a highly regulated environment. Work and Stress, 16, 18-36.

Hickman, J. S., \& Geller, E. S. (2003).A safety self-management intervention for mining operations. Journal of Safety Research, 34, 299-308.

Hinken, T.R. (1995). A review of scale development practices in the study of organizations. Journal of Management, 21, 967-988. 
Hsu, S. H., Lee, C. C., Wu, M. C., \& Takano, K. (2008). Cross-cultural study of organizational factors on safety: Japanese vs. Taiwanese oil refinery plants. Accident Analysis and Prevention, 40, 24-34. doi:10.1016/j.aap.2007.03.020

Hu, L., \& Bentler, P. M. (1999). Cutoff criteria for fit indexes in covariance structure analysis: Covariance criteria versus new alternatives. Structural Equation Modeling, $6,1-55$.

Janssens, M., Brett, J., \& Smith, F. (1995). Confirmatory cross-cultural research: Testing the viability of a corporation-wide safety policy. Academy of Management Journal, 38, 364-382.

Jung, T., Scott, T., Davies, H. T. O., Bower, P., Whalley, D., McNally, R., \& Mannion, R. (2009). Instruments for exploring organizational culture: A review of the literature. Public Administration Review, 6, 1087-1088. DOI: 10.1111/j.15406210.2009.02066.x

Kline, R.B. (2005). Principles and practice of structural equation modeling (2nd ed.). New York, NY: The Guilford Press.

Kotter, J. P., \& Heskett, J. L. (1992). Corporate culture and performance. New York, NY: Free Press.

Kunreuther, H. C., McNulty, P. J., \& Kang, Y. (2002).Third-party inpection as an alternative to command and control regulation. Risk Analysis, 22, 309-318.

Lee, T. (1998). Assessment of safety culture at a nuclear reprocessing plant. Work and Stress, $12,217-237$.

Lee, T., \& Harrison, K. (2000). Assessing safety culture in nuclear power stations. Safety Science, 30, 61-97. 
Ludwig, T. D., \& Geller, E. S. (2000). Intervening to improve the safety of delivery drivers: A systematic behavioral approach. Journal of Organizational Behavior Management, $19,1-124$.

Maher, K., Powers, S., \& Hughes, S. (2010, April 13). Mine disaster inquiry to focus on blasting. Wall Street Journal. Retrieved from http://www.wsj.com

McAdam, T. (2011, January 30). Employee suggestion program saves Kentucky millions. Louisville Examiner. Retrieved from http://www.examiner.com/louisville

McSween, T. E. (2011, March). Building Accountability for Leadership. Presented at Organizational Behavior Management Network Conference, Tampa, FL.

Mearns, K., Flin, R., Fleming, M., \& Gordon, R., (1997). Human and Organizational Factors in Offshore Safety. Report (OTH 543). Offshore Safety Division. HSE Books, Suffolk.

Montero, J. M., Araque, R. A., \& Rey, J. M. (2009). Occupational health and safety in the framework of corporate social responsibility. Safety Science, 47, 1440-1445. doi:10.1016/j.ssci.2009.03.002

Muthén, L.K., \& Muthén, B.O. (2002). Mplus user's guide. Los Angeles, CA: Muthén and Muthén.

Myers, J. (2010, May 20). A tale of two CEOs: BP vs. Massey, Part II, Don Blankenship of Massey [Web log post]. Retrieved from http://topics.nytimes.com/top/reference/ timestopics/subjects/m/mines_and_mining/mining_disasters/index.html.

National Safety Council. (2010). Injury Facts Book (NSC 2010 Edition). 
Nielsen, K. J., Carstensen, O., \& Rasmussen, K. (2006). The prevention of occupational injuries in two industrial plants using an incident reporting scheme. Journal of Safety Research, 37, 479-486.

Occupational Safety and Health Administration. (2003). Safety and Health Add Value. OSHA 3180. Retrieved from http://www.osha.gov/Publications/safety-healthaddvalue.pdf.

Ostrom, L., Wilhelmsen, C., \& Kaplan, B., (1993). Assessing safety culture. Nuclear Safety, 34, $163-172$.

Phillips, R., Cooper, D., Sutherland, V., \& Makin, P. (1993, April). A question of safety climate: Measuring perceptions of the working environment. Paper presented at the Annual Conference of the British Health and Safety Society, Birmingham.

Pidgeon, N. F. (1991). Safety culture and risk management in organizations. Journal of Cross-Cultural Psychology,22, 129-140. doi:10.1177/0022022191221009

Podgórski, D. (2006). Factors influencing implementation of occupational safety and health management systems by enterprises in Poland. Human Factors and Ergonomics in Manufacturing, 16, 255-267. doi:10.1002/hfm.20052

Redmon, W. D. \& Mason, M. A. (2001). Organizational culture and behavioral systems analysis. In C. M. Johnson, W. K. Redmon, \& T. C. Mawhinney (Eds.), Handbook of Organizational Performance: Behavior Analysis and Management (pp. 437-456). Binghamton, NY: Hawthorn.

Roberts, D. S. \& Geller, E. S. (1995). An actively caring model for occupational safety: A field test. Applied and Preventative Psychology, 4, 53-59.

Schein, E. H. (1990). Organizational culture. American Psychologist, 45, 109-119. 
Skinner, B. F. (1981). Selection by consequences. Science, 213, 501-504.

Smallman, C \& John, G. (2001). British directors perspectives on the impact of health and safety on corporate performance. Safety Science, 38, 227-239.

SPSS, Inc. (2009). SPSS 18.0 for Windows User's Guide. Chicago, IL: SPSS, Inc.

Stalnaker, C. K. (2006). Hawk's Nest Tunnel: A forgotten tragedy in safety's history. Professional Safety. 7, 27-33. doi: 0003-066X/90/S00.75.

Sulzer-Azaroff, B., McCann, K. B., \& Harris, T. C. (2001). The safe performance approach to preventing job-related illness and injury. In C. M. Johnson, W. K. Redmon, \& T. C. Mawhinney (Eds.), Handbook of Organizational Performance: Behavior Analysis and Management (pp. 437-456). Binghamton, NY: Hawthorn.

Tabachnick, B. G., and Fidell, L. S. (2007). Using multivariate statistics, 5th ed. Boston, MA: Allyn and Bacon.

Takala, J. (2002, May). Introductory Report: Decent Work - Safe Work. Report presented at the XVIth Word Congress on Safety and Health at Work, Vienna.

Tharaldsen, J. E., Mearns, K. J., \& Knudsen, K. (2010) Perspectives on safety: The impact of group membership, work factors and trust on safety performance in UK and Norwegian drislling company employees. Safety Science, 48, 1062-1072. doi:10.1016/j.ssci.2009.06.003

Towers Watson. (2010). Building a safer workplace: Minimize risk, maximize safety. Retrieved from http://www.towerswatson.com/research/1353.

Turner, N., Hershcovis, M. S., Chmiel, N., \&Walls, M. (2010). Life on the line: Job demands, perceived co-worker support for safety, and hazardous work events. Journal of Occupational Health Psychology, 15, 482-493. doi:10.1037/a0021004 
Van Exel N. J. A. \& de Graaf, G. (2005). Q methodology: A sneak preview. Retrieved from http://qmethod.org/articles/vanExel.pdf.

von Drehle, D. (2003). Triangle: The Fire That Changed America. New York, NY: Atlantic Monthly.

Washington State Department of Labor and Industries. (2009). Washington Administrative Code. (WAC 296-800-13020). Retrieved from http://www.lni.wa.gov/wisha/rules/corerules/PDFs/296-800-130.pdf

Zohar, D. (1980). Safety climate in industrial organisations: Theoretical and applied implications. Journal of Applied Psychology, 65, 96-102. 


\section{Appendix A}

IRB Exemption Approval.

To: Christopher Frazier

Psychology

From: Robin Tyndall, Institutional Review Board

Date: $2 / 02 / 2011$

RE: Notice of IRB Exemption

Study \#: 11-0189

Study Title: A HIERARCHICAL FACTOR ANALYSIS OF A SAFETY CULTURE

SURVEY

Exemption Category: (4) Collection or Study of Existing Data, If Public or Unable to Identify Subjects

This submission has been reviewed by the IRB Office and was determined to be exempt from further review according to the regulatory category cited above under 45 CFR 46.101(b). Should you change any aspect of the proposal, you must contact the IRB before implementing the changes to make sure the exempt status continues to apply. Otherwise, you do not need to request an annual renewal of IRB approval. Please notify the IRB Office when you have completed the study. 


\section{Appendix B}

Survey Items and Descriptive Statistics

\begin{tabular}{|c|c|c|c|c|c|c|c|c|}
\hline Items & $N$ & $M$ & Med & $S D$ & Skew & $\begin{array}{l}S E \\
\text { Skewness }\end{array}$ & Kurtosis & $\begin{array}{l}S E \\
\text { Kurtosis }\end{array}$ \\
\hline $\begin{array}{l}\text { 1. When rules or } \\
\text { procedures are } \\
\text { changed, the } \\
\text { changes are } \\
\text { promptly } \\
\text { communicated } \\
\text { to all affected } \\
\text { employees. }\end{array}$ & 25242 & 3.65 & 4.00 & 1.11 & -0.81 & 0.02 & -0.24 & 0.03 \\
\hline $\begin{array}{l}\text { 2. Senior } \\
\text { managers invest } \\
\text { sufficient money } \\
\text { and resources to } \\
\text { ensure a safe } \\
\text { work } \\
\text { environment. }\end{array}$ & 25220 & 3.77 & 4.00 & 0.97 & -0.95 & 0.02 & 0.66 & 0.03 \\
\hline $\begin{array}{l}\text { 3. When my } \\
\text { supervisor } \\
\text { corrects an } \\
\text { employee for at- } \\
\text { risk behavior, } \\
\text { s/he does so } \\
\text { respectfully. }\end{array}$ & 25150 & 3.86 & 4.00 & 0.96 & -1.09 & 0.02 & 1.13 & 0.03 \\
\hline $\begin{array}{l}\text { 4. When I see a } \\
\text { coworker } \\
\text { working at-risk, } \\
\text { I caution } \\
\text { him/her. }\end{array}$ & 25109 & 4.29 & 4.00 & 0.82 & -1.72 & 0.02 & 4.26 & 0.03 \\
\hline $\begin{array}{l}\text { 5. Employees } \\
\text { often "short cut" } \\
\text { safe work } \\
\text { practices. }\end{array}$ & 25161 & 2.46 & 2.00 & 1.14 & 0.51 & 0.02 & -0.70 & 0.03 \\
\hline $\begin{array}{l}\text { 6. Employees } \\
\text { help investigate } \\
\text { safety incidents. }\end{array}$ & 25156 & 3.55 & 4.00 & 1.05 & -0.74 & 0.02 & -0.10 & 0.03 \\
\hline $\begin{array}{l}\text { 7. When I see a } \\
\text { coworker doing } \\
\text { something } \\
\text { especially safe, I } \\
\text { acknowledge } \\
\text { him/her. }\end{array}$ & 25191 & 3.87 & 4.00 & 0.91 & -0.96 & 0.02 & 0.91 & 0.03 \\
\hline
\end{tabular}




\begin{tabular}{|c|c|c|c|c|c|c|c|c|}
\hline Items & $N$ & $M$ & Med & $S D$ & Skew & SE Skew & Kurtosis & $\begin{array}{l}S E \\
\text { Kurtosis }\end{array}$ \\
\hline $\begin{array}{l}\text { 8. Senior } \\
\text { managers spend } \\
\text { time talking one- } \\
\text { on-one with } \\
\text { employees about } \\
\text { safety. }\end{array}$ & 25148 & 3.22 & 3.00 & 1.18 & -0.32 & 0.02 & -0.91 & 0.03 \\
\hline $\begin{array}{l}\text { 9. Senior } \\
\text { managers seem } \\
\text { genuinely } \\
\text { interested in } \\
\text { reducing } \\
\text { injuries. }\end{array}$ & 25161 & 3.99 & 4.00 & 0.97 & -1.21 & 0.02 & 1.39 & 0.03 \\
\hline $\begin{array}{l}\text { 10. My } \\
\text { supervisor } \\
\text { regularly asks } \\
\text { employees about } \\
\text { safety concerns } \\
\text { and ideas to } \\
\text { improve safety. }\end{array}$ & 25189 & 3.83 & 4.00 & 1.03 & -1.01 & 0.02 & 0.57 & 0.03 \\
\hline $\begin{array}{l}\text { 11. When an } \\
\text { employee is } \\
\text { injured, he or } \\
\text { she will likely be } \\
\text { punished } \\
\text { regardless of the } \\
\text { causes and } \\
\text { circumstances. }\end{array}$ & 25158 & 2.54 & 2.00 & 1.17 & 0.46 & 0.02 & -0.72 & 0.03 \\
\hline $\begin{array}{l}\text { 12. The safety } \\
\text { committees' } \\
\text { efforts help } \\
\text { improve safety. }\end{array}$ & 25095 & 3.72 & 4.00 & 0.95 & -0.83 & 0.02 & 0.56 & 0.03 \\
\hline $\begin{array}{l}\text { 13. The results } \\
\text { of safety audits } \\
\text { and inspections } \\
\text { are regularly } \\
\text { shared with all } \\
\text { employees. }\end{array}$ & 25211 & 3.54 & 4.00 & 1.08 & -0.68 & 0.02 & -0.35 & 0.03 \\
\hline $\begin{array}{l}\text { 14. The people } \\
\text { who lead safety } \\
\text { efforts (e.g., } \\
\text { safety reps, } \\
\text { safety managers) } \\
\text { have enough } \\
\text { influence and } \\
\text { staffing to } \\
\text { adequately } \\
\text { support safety. }\end{array}$ & 25215 & 3.49 & 4.00 & 1.01 & -0.63 & 0.02 & -0.18 & 0.03 \\
\hline
\end{tabular}




\begin{tabular}{|c|c|c|c|c|c|c|c|c|}
\hline Items & $N$ & $M$ & Med & $S D$ & Skew & $S E$ Skew & Kurtosis & $\begin{array}{l}S E \\
\text { Kurtosis }\end{array}$ \\
\hline $\begin{array}{l}15 . \text { The } \\
\text { organization's } \\
\text { safety } \\
\text { improvement } \\
\text { goals and efforts } \\
\text { are regularly } \\
\text { discussed with } \\
\text { employees. }\end{array}$ & 25222 & 3.75 & 4.00 & 0.93 & -0.98 & 0.02 & 0.70 & 0.03 \\
\hline $\begin{array}{l}\text { 16. The hiring/ } \\
\text { promotion } \\
\text { process selects } \\
\text { employees with } \\
\text { the ability and } \\
\text { motivation to } \\
\text { work safely. }\end{array}$ & 25209 & 3.42 & 4.00 & 1.10 & -0.53 & 0.02 & -0.38 & 0.03 \\
\hline $\begin{array}{l}\text { 17. Safety } \\
\text { audits/inspection } \\
\text { s are conducted } \\
\text { regularly in my } \\
\text { area. }\end{array}$ & 25207 & 3.86 & 4.00 & 0.92 & -1.06 & 0.02 & 1.11 & 0.03 \\
\hline $\begin{array}{l}\text { 18. People are } \\
\text { disciplined when } \\
\text { they should be } \\
\text { for willful } \\
\text { serious or } \\
\text { repeated safety } \\
\text { violations. }\end{array}$ & 25169 & 3.75 & 4.00 & 0.98 & -0.87 & 0.02 & 0.49 & 0.03 \\
\hline $\begin{array}{l}\text { 19. Our wellness } \\
\text { program is } \\
\text { effective at } \\
\text { encouraging } \\
\text { healthy } \\
\text { behaviors. }\end{array}$ & 25113 & 3.60 & 4.00 & 0.98 & -0.69 & 0.02 & 0.15 & 0.03 \\
\hline $\begin{array}{l}\text { 20. Standard } \\
\text { operating } \\
\text { procedures have } \\
\text { been developed } \\
\text { for all critical } \\
\text { tasks. }\end{array}$ & 25204 & 3.78 & 4.00 & 0.93 & -0.97 & 0.02 & 0.86 & 0.03 \\
\hline $\begin{array}{l}\text { 21. Some safety } \\
\text { rules and } \\
\text { procedures are } \\
\text { not consistently } \\
\text { enforced. }\end{array}$ & 25194 & 2.96 & 3.00 & 1.15 & -0.03 & 0.02 & -1.08 & 0.03 \\
\hline
\end{tabular}




\begin{tabular}{|c|c|c|c|c|c|c|c|c|}
\hline Items & $N$ & $M$ & Med & $S D$ & Skew & $S E$ Skew & Kurtosis & $\begin{array}{l}S E \\
\text { Kurtosis }\end{array}$ \\
\hline $\begin{array}{l}\text { 22. Serious } \\
\text { safety violations } \\
\text { are treated the } \\
\text { same whether or } \\
\text { not an injury } \\
\text { occurs. }\end{array}$ & 25198 & 3.53 & 4.00 & 1.04 & -0.69 & 0.02 & -0.21 & 0.03 \\
\hline $\begin{array}{l}\text { 23. My } \\
\text { supervisor does } \\
\text { not put } \\
\text { production } \\
\text { ahead of safety. }\end{array}$ & 25198 & 3.61 & 4.00 & 1.16 & -0.73 & 0.02 & -0.35 & 0.03 \\
\hline $\begin{array}{l}\text { 24. Employees } \\
\text { are involved in } \\
\text { designing the } \\
\text { safety reward/ } \\
\text { recognition } \\
\text { program. }\end{array}$ & 25222 & 3.06 & 3.00 & 1.12 & -0.21 & 0.02 & -0.76 & 0.03 \\
\hline $\begin{array}{l}25 . \text { Employees } \\
\text { are involved in } \\
\text { conducting } \\
\text { safety audits and } \\
\text { inspections. }\end{array}$ & 25209 & 3.53 & 4.00 & 1.05 & -0.77 & 0.02 & -0.07 & 0.03 \\
\hline $\begin{array}{l}\text { 26. My } \\
\text { supervisor } \\
\text { clearly sets the } \\
\text { expectation that } \\
\text { employees must } \\
\text { follow all safety } \\
\text { rules and } \\
\text { procedures. }\end{array}$ & 25207 & 4.04 & 4.00 & 0.89 & -1.34 & 0.02 & 2.24 & 0.03 \\
\hline $\begin{array}{l}\text { 27. Senior } \\
\text { managers place } \\
\text { most of the } \\
\text { blame for an } \\
\text { injury on the } \\
\text { injured } \\
\text { employee. }\end{array}$ & 25159 & 2.94 & 3.00 & 1.19 & 0.13 & 0.02 & -0.96 & 0.03 \\
\hline $\begin{array}{l}\text { 28. My } \\
\text { supervisor often } \\
\text { gives me } \\
\text { positive } \\
\text { feedback when } \\
\text { s/he sees me } \\
\text { working safely. }\end{array}$ & 25113 & 3.53 & 4.00 & 1.05 & -0.70 & 0.02 & -0.13 & 0.03 \\
\hline
\end{tabular}




\begin{tabular}{|c|c|c|c|c|c|c|c|c|}
\hline Items & $N$ & $M$ & Med & $S D$ & Skew & SE Skew & Kurtosis & $\begin{array}{l}S E \\
\text { Kurtosis }\end{array}$ \\
\hline $\begin{array}{l}29 . \text { I have } \\
\text { received } \\
\text { adequate } \\
\text { training to be } \\
\text { able to work } \\
\text { safely. }\end{array}$ & 25204 & 4.09 & 4.00 & 0.82 & -1.36 & 0.02 & 2.79 & 0.03 \\
\hline $\begin{array}{l}\text { 30. I am } \\
\text { comfortable } \\
\text { raising safety } \\
\text { concerns to my } \\
\text { supervisor and } \\
\text { manager. }\end{array}$ & 25194 & 4.00 & 4.00 & 0.94 & -1.31 & 0.02 & 1.85 & 0.03 \\
\hline $\begin{array}{l}\text { 31. Senior } \\
\text { managers fully } \\
\text { understand the } \\
\text { real safety issues } \\
\text { in the } \\
\text { workplace. }\end{array}$ & 25198 & 3.53 & 4.00 & 1.06 & -0.67 & 0.02 & -0.26 & 0.03 \\
\hline $\begin{array}{l}\text { 32Senior } \\
\text { managers do not } \\
\text { put production } \\
\text { ahead of safety. }\end{array}$ & 25198 & 3.50 & 4.00 & 1.11 & -0.62 & 0.02 & -0.37 & 0.03 \\
\hline $\begin{array}{l}\text { 33. Senior } \\
\text { managers are } \\
\text { more concerned } \\
\text { about keeping } \\
\text { the injury } \\
\text { statistics low } \\
\text { than with truly } \\
\text { keeping people } \\
\text { safe. }\end{array}$ & 25185 & 2.84 & 3.00 & 1.18 & 0.19 & 0.02 & -0.95 & 0.03 \\
\hline $\begin{array}{l}\text { 34. Senior } \\
\text { management } \\
\text { encourages } \\
\text { preventive } \\
\text { maintenance } \\
\text { instead of just } \\
\text { reacting to } \\
\text { problems once } \\
\text { they occur. }\end{array}$ & 25216 & 3.53 & 4.00 & 1.02 & -0.72 & 0.02 & -0.05 & 0.03 \\
\hline $\begin{array}{l}\text { 35. Safety rules } \\
\text { and procedures } \\
\text { are regularly } \\
\text { reviewed with } \\
\text { employees. }\end{array}$ & 25196 & 3.61 & 4.00 & 0.97 & -0.80 & 0.02 & 0.10 & 0.03 \\
\hline
\end{tabular}




\begin{tabular}{|c|c|c|c|c|c|c|c|c|}
\hline Items & $N$ & $M$ & Med & $S D$ & Skew & $S E$ Skew & Kurtosis & $\begin{array}{l}S E \\
\text { Kurtosis }\end{array}$ \\
\hline $\begin{array}{l}\text { 36. Safety } \\
\text { meetings help } \\
\text { improve safety. }\end{array}$ & 25243 & 3.98 & 4.00 & 0.92 & -1.15 & 0.02 & 1.37 & 0.03 \\
\hline $\begin{array}{l}\text { 37. Safety } \\
\text { meetings are } \\
\text { regularly } \\
\text { conducted in my } \\
\text { area. }\end{array}$ & 25208 & 4.07 & 4.00 & 0.89 & -1.32 & 0.02 & 2.07 & 0.03 \\
\hline $\begin{array}{l}\text { 38. Safety is not } \\
\text { compromised } \\
\text { when } \\
\text { determining } \\
\text { production } \\
\text { schedules, } \\
\text { overtime, and } \\
\text { staffing. }\end{array}$ & 25223 & 3.54 & 4.00 & 1.06 & -0.63 & 0.02 & -0.24 & 0.03 \\
\hline $\begin{array}{l}\text { 39. Safety is } \\
\text { considered when } \\
\text { purchasing new } \\
\text { tools/ } \\
\text { equipment. }\end{array}$ & 25267 & 3.77 & 4.00 & 0.95 & -0.94 & 0.02 & 0.86 & 0.03 \\
\hline $\begin{array}{l}\text { 40. Lessons } \\
\text { learned from } \\
\text { incidents and } \\
\text { injuries are } \\
\text { communicated } \\
\text { to all relevant } \\
\text { people. }\end{array}$ & 25085 & 3.88 & 4.00 & 0.93 & -1.11 & 0.02 & 1.19 & 0.03 \\
\hline $\begin{array}{l}\text { 41. Safety is } \\
\text { considered when } \\
\text { changes are } \\
\text { made to rules } \\
\text { and procedures. }\end{array}$ & 25137 & 3.62 & 4.00 & 1.01 & -0.86 & 0.02 & 0.19 & 0.03 \\
\hline $\begin{array}{l}\text { 42. Safety } \\
\text { incidents that } \\
\text { happen within } \\
\text { this workplace } \\
\text { and elsewhere } \\
\text { are reviewed } \\
\text { regularly with } \\
\text { employees. }\end{array}$ & 25154 & 3.82 & 4.00 & 0.89 & -1.06 & 0.02 & 1.08 & 0.03 \\
\hline
\end{tabular}




\begin{tabular}{|c|c|c|c|c|c|c|c|c|}
\hline Items & $N$ & $M$ & Med & $S D$ & Skew & SE Skew & Kurtosis & $\begin{array}{l}S E \\
\text { Kurtosis }\end{array}$ \\
\hline $\begin{array}{l}\text { 43. When } \\
\text { employees } \\
\text { correct each } \\
\text { others' at-risk } \\
\text { behavior, they } \\
\text { do so } \\
\text { respectfully. }\end{array}$ & 25162 & 3.81 & 4.00 & 0.85 & -1.01 & 0.02 & 1.37 & 0.03 \\
\hline $\begin{array}{l}\text { 44. When asked } \\
\text { to do a new job } \\
\text { or task, I receive } \\
\text { enough training } \\
\text { to be able to do } \\
\text { it safely. }\end{array}$ & 25144 & 3.80 & 4.00 & 0.92 & -1.01 & 0.02 & 0.99 & 0.03 \\
\hline $\begin{array}{l}\text { 45. Safety } \\
\text { hazards found } \\
\text { during } \\
\text { inspections are } \\
\text { followed-up on } \\
\text { quickly. }\end{array}$ & 25122 & 3.73 & 4.00 & 0.97 & -0.92 & 0.02 & 0.49 & 0.03 \\
\hline
\end{tabular}

\begin{tabular}{|c|c|c|c|c|c|c|c|c|}
\hline $\begin{array}{l}\text { 46. Safety } \\
\text { audits/inspection } \\
\text { s are effective in } \\
\text { identifying and } \\
\text { correcting safety } \\
\text { hazards. }\end{array}$ & 25173 & 3.90 & 4.00 & 0.82 & -1.07 & 0.02 & 1.71 & 0.03 \\
\hline $\begin{array}{l}\text { 47. Our } \\
\text { company } \\
\text { recognizes or } \\
\text { celebrates safety } \\
\text { achievements or } \\
\text { milestones. }\end{array}$ & 25243 & 3.61 & 4.00 & 1.09 & -0.82 & 0.02 & 0.02 & 0.03 \\
\hline $\begin{array}{l}\text { 48. New } \\
\text { employees } \\
\text { receive enough } \\
\text { training before } \\
\text { doing the job on } \\
\text { their own. }\end{array}$ & 25208 & 3.74 & 4.00 & 1.01 & -0.90 & 0.02 & 0.37 & 0.03 \\
\hline $\begin{array}{l}\text { 49. My } \\
\text { supervisor } \\
\text { would give me } \\
\text { corrective } \\
\text { feedback if s/he } \\
\text { sees me working } \\
\text { at-risk. }\end{array}$ & 25223 & 4.03 & 4.00 & 0.82 & -1.33 & 0.02 & 2.71 & 0.03 \\
\hline
\end{tabular}




\begin{tabular}{|c|c|c|c|c|c|c|c|c|}
\hline Items & $N$ & $M$ & Med & $S D$ & Skew & $S E$ Skew & Kurtosis & $\begin{array}{l}S E \\
\text { Kurtosis }\end{array}$ \\
\hline $\begin{array}{l}\text { 50. Our training } \\
\text { program ensures } \\
\text { all employees } \\
\text { who do the same } \\
\text { job learn to do it } \\
\text { the same way. }\end{array}$ & 25198 & 3.44 & 4.00 & 1.04 & -0.59 & 0.02 & -0.38 & 0.03 \\
\hline $\begin{array}{l}\text { 51. Our safety } \\
\text { reward/recogniti } \\
\text { on program(s) } \\
\text { encourage } \\
\text { employees to } \\
\text { work safely and } \\
\text { participate in } \\
\text { safety activities. }\end{array}$ & 25085 & 3.50 & 4.00 & 1.08 & -0.61 & 0.02 & -0.31 & 0.03 \\
\hline $\begin{array}{l}\text { 52. Employee } \\
\text { safety } \\
\text { suggestions are } \\
\text { taken seriously. }\end{array}$ & 25137 & 3.65 & 4.00 & 0.99 & -0.88 & 0.02 & 0.36 & 0.03 \\
\hline $\begin{array}{l}\text { 53. Our safety } \\
\text { reward/ } \\
\text { recognition } \\
\text { program is fair. }\end{array}$ & 25154 & 3.30 & 3.00 & 1.04 & -0.46 & 0.02 & -0.30 & 0.03 \\
\hline
\end{tabular}

54. Our safety audits/

inspections

focus on safe

work behaviors

in addition to

safe work

conditions.

$\begin{array}{lll}25162 & 3.75 & 4.00\end{array}$

$0.88-1.01$

0.02

1.07

0.03

55. I tend to

work more risky

when

supervisors

aren't present.

$\begin{array}{llll}25144 & 2.04 & 2.00\end{array}$

$1.08 \quad 1.06$

0.02

0.42

0.03

\section{Our}

employee

assistance

program helps

people manage

personal

problems which

may impact

safety.

$25122 \quad 3.43 \quad 4.00$

$0.90 \quad-0.53$

0.02

0.37

0.03 


\begin{tabular}{|c|c|c|c|c|c|c|c|c|}
\hline Items & $N$ & $M$ & Med & $S D$ & Skew & SE Skew & Kurtosis & $\begin{array}{l}S E \\
\text { Kurtosis }\end{array}$ \\
\hline $\begin{array}{l}\text { 57. Employees } \\
\text { fully understand } \\
\text { the potential } \\
\text { hazards of their } \\
\text { jobs. }\end{array}$ & 25173 & 3.80 & 4.00 & 0.92 & -0.96 & 0.02 & 0.63 & 0.03 \\
\hline $\begin{array}{l}58 . \text { Employees } \\
\text { correct safety } \\
\text { hazards } \\
\text { themselves when } \\
\text { appropriate. }\end{array}$ & 25144 & 3.80 & 4.00 & 0.84 & -1.15 & 0.02 & 1.60 & 0.03 \\
\hline $\begin{array}{l}\text { 59. Employees } \\
\text { correct safety } \\
\text { hazards } \\
\text { themselves when } \\
\text { appropriate. }\end{array}$ & 25135 & 3.80 & 4.00 & 0.84 & -1.15 & 0.02 & 1.60 & 0.03 \\
\hline $\begin{array}{l}60 . \text { My } \\
\text { supervisor } \\
\text { sometimes } \\
\text { encourages } \\
\text { employees to } \\
\text { overlook hazards } \\
\text { to get the job } \\
\text { done. }\end{array}$ & 25180 & 2.11 & 2.00 & 1.13 & 0.91 & 0.02 & -0.04 & 0.03 \\
\hline $\begin{array}{l}\text { 61. My } \\
\text { supervisor sets a } \\
\text { good example } \\
\text { for safety } \\
\text { through his/her } \\
\text { own safe } \\
\text { behaviors. }\end{array}$ & 25176 & 3.86 & 4.00 & 0.92 & -1.12 & 0.02 & 1.44 & 0.03 \\
\hline $\begin{array}{l}62 . \\
\text { Improvements } \\
\text { made from } \\
\text { employee safety } \\
\text { suggestions are } \\
\text { communicated } \\
\text { to all. }\end{array}$ & 25155 & 3.54 & 4.00 & 0.98 & -0.70 & 0.02 & -0.15 & 0.03 \\
\hline $\begin{array}{l}\text { 63. My } \\
\text { supervisor } \\
\text { quickly } \\
\text { addresses } \\
\text { identified } \\
\text { hazards. }\end{array}$ & 25165 & 3.83 & 4.00 & 0.88 & -1.09 & 0.02 & 1.41 & 0.03 \\
\hline
\end{tabular}




\begin{tabular}{|c|c|c|c|c|c|c|c|c|}
\hline Items & $N$ & $M$ & Med & $S D$ & Skew & $S E$ Skew & Kurtosis & $\begin{array}{l}S E \\
\text { Kurtosis }\end{array}$ \\
\hline $\begin{array}{l}\text { 64. Employees } \\
\text { who actively } \\
\text { participate in } \\
\text { safety activities } \\
\text { are recognized } \\
\text { for their efforts. }\end{array}$ & 25188 & 3.30 & 3.00 & 1.07 & -0.41 & 0.02 & -0.56 & 0.03 \\
\hline $\begin{array}{l}65 . \text { Employees } \\
\text { receive quick } \\
\text { responses to } \\
\text { their safety } \\
\text { suggestions, } \\
\text { whether they are } \\
\text { accepted or not. }\end{array}$ & 25152 & 3.26 & 3.00 & 1.00 & -0.42 & 0.02 & -0.47 & 0.03 \\
\hline $\begin{array}{l}\text { 66. In addition } \\
\text { to working } \\
\text { safely, most } \\
\text { employees } \\
\text { regularly do } \\
\text { other things to } \\
\text { improve safety. }\end{array}$ & 25157 & 3.72 & 4.00 & 0.81 & -0.91 & 0.02 & 1.00 & 0.03 \\
\hline $\begin{array}{l}\text { 67. Minor } \\
\text { injuries often go } \\
\text { unreported. }\end{array}$ & 25167 & 2.85 & 3.00 & 1.18 & 0.12 & 0.02 & -1.04 & 0.03 \\
\hline $\begin{array}{l}\text { 68. Meeting } \\
\text { production goals } \\
\text { often requires } \\
\text { employees to put } \\
\text { themselves at- } \\
\text { risk. }\end{array}$ & 25088 & 2.42 & 2.00 & 1.15 & 0.57 & 0.02 & -0.61 & 0.03 \\
\hline $\begin{array}{l}\text { 69. Managers, } \\
\text { supervisors, and } \\
\text { employees all } \\
\text { know what } \\
\text { behaviors will } \\
\text { result in } \\
\text { discipline. }\end{array}$ & 25055 & 3.69 & 4.00 & 0.94 & -0.96 & 0.02 & 0.67 & 0.03 \\
\hline $\begin{array}{l}70 . \text { Employees } \\
\text { acknowledge } \\
\text { each other for } \\
\text { especially safe } \\
\text { behaviors. }\end{array}$ & 25076 & 3.58 & 4.00 & 0.92 & -0.74 & 0.02 & 0.09 & 0.03 \\
\hline $\begin{array}{l}71 . \text { When I have } \\
\text { a near miss or } \\
\text { close call, I } \\
\text { report it. }\end{array}$ & 25112 & 3.70 & 4.00 & 0.99 & -0.86 & 0.02 & 0.30 & 0.03 \\
\hline
\end{tabular}




\begin{tabular}{|c|c|c|c|c|c|c|c|c|}
\hline Items & $N$ & $M$ & Med & $S D$ & Skew & $S E$ Skew & Kurtosis & $\begin{array}{l}S E \\
\text { Kurtosis }\end{array}$ \\
\hline $\begin{array}{l}\text { 72. Discipline } \\
\text { for safety } \\
\text { violations is fair } \\
\text { and consistent. }\end{array}$ & 25103 & 3.30 & 4.00 & 1.07 & -0.50 & 0.02 & -0.51 & 0.03 \\
\hline $\begin{array}{l}\text { 73. If I have a } \\
\text { safety } \\
\text { suggestion or } \\
\text { concern, I let } \\
\text { someone know. }\end{array}$ & 25066 & 4.03 & 4.00 & 0.72 & -1.37 & 0.02 & 3.74 & 0.03 \\
\hline $\begin{array}{l}\text { 74. If I have a } \\
\text { minor injury, I'll } \\
\text { report it. }\end{array}$ & 25080 & 3.78 & 4.00 & 0.99 & -0.96 & 0.02 & 0.54 & 0.03 \\
\hline $\begin{array}{l}75 . \text { If a } \\
\text { coworker saw } \\
\text { me doing } \\
\text { something at- } \\
\text { risk, I would } \\
\text { want them to say } \\
\text { something to } \\
\text { me. }\end{array}$ & 25116 & 4.20 & 4.00 & 0.80 & -1.52 & 0.02 & 3.67 & 0.03 \\
\hline $\begin{array}{l}\text { 76. I use what I } \\
\text { learn at work to } \\
\text { improve safety } \\
\text { at home. }\end{array}$ & 25127 & 4.11 & 4.00 & 0.83 & -1.33 & 0.02 & 2.63 & 0.03 \\
\hline $\begin{array}{l}77 \text {. I understand } \\
\text { all rules and } \\
\text { procedures } \\
\text { required to } \\
\text { perform my job } \\
\text { safely. }\end{array}$ & 25041 & 4.11 & 4.00 & 0.76 & -1.33 & 0.02 & 3.15 & 0.03 \\
\hline $\begin{array}{l}\text { 78. Employees } \\
\text { who work safely } \\
\text { benefit through } \\
\text { either a better } \\
\text { performance } \\
\text { review, chance } \\
\text { for promotion, } \\
\text { better job } \\
\text { assignments, or } \\
\text { some other } \\
\text { 'perk'. }\end{array}$ & 25041 & 3.23 & 3.00 & 1.18 & -0.36 & 0.02 & -0.79 & 0.03 \\
\hline $\begin{array}{l}79 . \text { I only get } \\
\text { involved in } \\
\text { safety activities } \\
\text { because I'm } \\
\text { required to do } \\
\text { so. }\end{array}$ & 25036 & 2.33 & 2.00 & 1.09 & 0.74 & 0.02 & -0.18 & 0.03 \\
\hline
\end{tabular}




\begin{tabular}{|c|c|c|c|c|c|c|c|c|}
\hline Items & $N$ & $M$ & Med & $S D$ & Skew & SE Skew & Kurtosis & $\begin{array}{l}S E \\
\text { Kurtosis }\end{array}$ \\
\hline $\begin{array}{l}\text { 80. I often "short } \\
\text { cut" safe work } \\
\text { practices. }\end{array}$ & 25108 & 1.92 & 2.00 & 1.00 & 1.31 & 0.02 & 1.39 & 0.03 \\
\hline $\begin{array}{l}\text { 81. Employees } \\
\text { should caution } \\
\text { each other about } \\
\text { at-risk } \\
\text { behaviors. }\end{array}$ & 25128 & 4.20 & 4.00 & 0.73 & -1.48 & 0.02 & 4.37 & 0.03 \\
\hline $\begin{array}{l}\text { 82. Employees } \\
\text { should } \\
\text { acknowledge } \\
\text { each other for } \\
\text { especially safe } \\
\text { behaviors. }\end{array}$ & 25146 & 4.14 & 4.00 & 0.74 & -1.36 & 0.02 & 3.80 & 0.03 \\
\hline $\begin{array}{l}\text { 83. Hazards are } \\
\text { prioritized and } \\
\text { corrected based } \\
\text { on potential for } \\
\text { injury. }\end{array}$ & 25055 & 3.71 & 4.00 & 0.92 & -0.91 & 0.02 & 0.72 & 0.03 \\
\hline $\begin{array}{l}\text { 84. Following all } \\
\text { safety rules and } \\
\text { procedures } \\
\text { needlessly slows } \\
\text { down my job. }\end{array}$ & 25091 & 2.44 & 2.00 & 1.13 & 0.64 & 0.02 & -0.50 & 0.03 \\
\hline $\begin{array}{l}\text { 85. Everyone is } \\
\text { held to the same } \\
\text { safety standard } \\
\text { (e.g., all } \\
\text { departments, } \\
\text { contractors). }\end{array}$ & 25079 & 3.56 & 4.00 & 1.16 & -0.71 & 0.02 & -0.40 & 0.03 \\
\hline $\begin{array}{l}\text { 86. Employees } \\
\text { help establish } \\
\text { and/or change } \\
\text { safety rules, } \\
\text { regulations, } \\
\text { policies, and/or } \\
\text { procedures. }\end{array}$ & 25074 & 3.45 & 4.00 & 1.01 & -0.66 & 0.02 & -0.17 & 0.03 \\
\hline $\begin{array}{l}87 . \text { All } \\
\text { incidents, even } \\
\text { minor ones, are } \\
\text { thoroughly } \\
\text { investigated if } \\
\text { they have } \\
\text { potential for } \\
\text { serious injury. }\end{array}$ & 25078 & 3.80 & 4.00 & 0.94 & -0.98 & 0.02 & 0.84 & 0.03 \\
\hline
\end{tabular}




\begin{tabular}{|c|c|c|c|c|c|c|c|c|}
\hline Items & $N$ & $M$ & Med & $S D$ & Skew & $S E$ Skew & Kurtosis & $\begin{array}{l}S E \\
\text { Kurtosis }\end{array}$ \\
\hline $\begin{array}{l}\text { 88. All factors } \\
\text { (e.g., inadequate } \\
\text { training, } \\
\text { production } \\
\text { pressure, } \\
\text { excessive } \\
\text { overtime) are } \\
\text { adequately } \\
\text { considered } \\
\text { during incident } \\
\text { analyses. }\end{array}$ & 25061 & 3.48 & 4.00 & 1.01 & -0.64 & 0.02 & -0.03 & 0.03 \\
\hline $\begin{array}{l}\text { 89. Alcohol or } \\
\text { drug abuse is a } \\
\text { problem at my } \\
\text { site. }\end{array}$ & 25133 & 2.23 & 2.00 & 1.26 & 0.85 & 0.02 & -0.34 & 0.03 \\
\hline $\begin{array}{l}\text { 90. Employees } \\
\text { caution each } \\
\text { other about at- } \\
\text { risk behaviors. }\end{array}$ & 25088 & 3.49 & 4.00 & 1.00 & -0.69 & 0.02 & -0.16 & 0.03 \\
\hline $\begin{array}{l}\text { 91. Employees } \\
\text { are kept } \\
\text { informed of the } \\
\text { safety } \\
\text { committees' } \\
\text { activities. }\end{array}$ & 25126 & 3.84 & 4.00 & 0.82 & -1.10 & 0.02 & 1.58 & 0.03 \\
\hline $\begin{array}{l}\text { 92. Employees } \\
\text { appreciate } \\
\text { feedback from } \\
\text { coworkers for } \\
\text { at-risk } \\
\text { behaviors. }\end{array}$ & 25101 & 3.78 & 4.00 & 0.82 & -1.00 & 0.02 & 1.27 & 0.03 \\
\hline
\end{tabular}

Note. $N=$ Total participants; $M=$ Mean; Med $=$ Median; $S D=$ Standard Deviation; Skew $=$ Skewness;

$S E$ Skew $=$ Standard error of skewness; $S E$ Kurtosis $=$ Standard error of kurtosis. 
Table 1

Exploratory Factor Analysis Eigenvalues and Percent of Variance

\begin{tabular}{llll}
\hline & & Variance & Cumulative \\
Factor & Eigenvalue & Percentage & Percentage \\
\hline 1 & 26.06 & 28.32 & 28.32 \\
2 & 4.13 & 4.49 & 32.81 \\
3 & 2.94 & 3.20 & 36.01 \\
4 & 2.56 & 2.79 & 38.80 \\
5 & 1.66 & 1.80 & 40.60 \\
6 & 1.54 & 1.68 & 42.28 \\
7 & 1.46 & 1.58 & 43.86 \\
8 & 1.30 & 1.41 & 45.27 \\
9 & 1.23 & 1.34 & 46.61 \\
11 & 1.16 & 1.26 & 47.87 \\
\hline 12 & 1.03 & 1.12 & 50.15 \\
\hline
\end{tabular}


Table 2

Exploratory Factor Analysis Factor Description

\begin{tabular}{ll}
\hline Factor & Factor Description \\
\hline 1 & Training and Rules \\
2 & Peer Support Caution Others \\
3 & Risk Taking \\
4 & Peer Support Respectful Feedback \\
5 & Reward/Recognition \\
6 & Supervisor Concern \\
7 & Senior Management Concern \\
8 & Discipline and Investigation \\
9 & Incident Reporting \\
10 & Communication \\
11 & Senior Management and/or Supervisor Blame \\
&
\end{tabular}


Table 3

Exploratory Factor Analysis Pattern Matrix Factor Loadings

\begin{tabular}{lllllllllllll}
\hline & 1 & 2 & 3 & 4 & 5 & 6 & 7 & 8 & 9 & 10 & 11 & 12
\end{tabular}

48. New employees receive .495

enough training before doing the

job on their own.

50. Our training program ensures .479

all employees who do the same

job learn to do it the same way.

57. Employees fully understand .465

the potential hazards of their jobs.

20. Standard operating procedures .445

have been developed for all

critical tasks.

29. I have received adequate

training to be able to work safely.

44. When asked to do a new job

or task, I receive enough training

to be able to do it safely.

36. Safety meetings help improve safety.

19. Our wellness program is

effective at encouraging healthy

behaviors.

77. I understand all rules and

procedures required to perform

my job safely.

82. Employees should

acknowledge each other for

especially safe behaviors.

81. Employees should caution

$-.636$

each other about at-risk behaviors.

75. If a coworker saw me doing something at-risk, I would want them to say something to me.

76. I use what I learn at work to

improve safety at home.

$-.578$

73. If I have a safety suggestion or

concern, I let someone know.

4. When I see a coworker working

$-.392$ at-risk, I caution him/her. 
80. I often "short cut" safe work practices.

55. I tend to work more risky when supervisors aren't present.

84. Following all safety rules and procedures needlessly slows down my job.

79. I only get involved in safety activities because I'm required to do so.

67. Minor injuries often go unreported.

68. Meeting production goals often requires employees to put themselves at-risk.

60. My supervisor sometimes encourages employees to overlook hazards to get the job done.

90. Employees caution each other about at-risk behaviors.

92. Employees appreciate feedback from coworkers for atrisk behaviors.

70. Employees acknowledge each other for especially safe behaviors.

43. When employees correct each others' at-risk behavior, they do so respectfully.

66. In addition to working safely, most employees regularly do other things to improve safety.

53. Our safety reward/recognition program is fair.

51. Our safety reward/recognition program(s) encourage employees to work safely and participate in safety activities.

64. Employees who actively

participate in safety activities are recognized for their efforts. 
24. Employees are involved in

$\begin{array}{llllllllllll}1 & 2 & 3 & 4 & 5 & 6 & 7 & 8 & 9 & 10 & 11 & 12\end{array}$

designing the safety .623

reward/recognition program.

47. Our company recognizes or .604 celebrates safety achievements or milestones.

78. Employees who work safely benefit through either a better performance review, chance for promotion, better job assignments, or some other 'perk'.

65. Employees receive quick responses to their safety suggestions, whether they are accepted or not.

56. Our employee assistance program helps people manage personal problems which may impact safety.

52. Employee safety suggestions are taken seriously.

28. My supervisor often gives me positive feedback when s/he sees me working safely.

10. My supervisor regularly asks employees about safety concerns and ideas to improve safety.

61. My supervisor sets a good example for safety through his/her own safe behaviors.

49. My supervisor would give me corrective feedback if $\mathrm{s} / \mathrm{he}$ sees me working at-risk.

3. When my supervisor corrects an employee for at-risk behavior, s/he does so respectfully.

63. My supervisor quickly addresses identified hazards.

26. My supervisor clearly sets the expectation that employees must follow all safety rules and procedures. 


\begin{tabular}{lllllllllllll}
\hline & 1 & 2 & 3 & 4 & 5 & 6 & 7 & 8 & 9 & 10 & 11 & 12
\end{tabular}

30. I am comfortable raising

safety concerns to my supervisor

and manager.

9. Senior managers seem

genuinely interested in reducing

injuries.

8. Senior managers spend time

talking one-on-one with

employees about safety.

22. Serious safety violations are

treated the same whether or not an

injury occurs.

18. People are disciplined when

they should be for willful serious

or repeated safety violations.

69. Managers, supervisors, and

employees all know what

behaviors will result in discipline.

88. All factors (e.g., inadequate

training, production pressure,

excessive overtime) are

adequately considered during

incident analyses.

72. Discipline for safety violations

is fair and consistent.

83. Hazards are prioritized and

corrected based on potential for

injury.

87. All incidents, even minor

ones, are thoroughly investigated

if they have potential for serious

injury.

71. When I have a near miss or

close call, I report it.

74. If I have a minor injury, I'll report it.

42. Safety incidents that happen within this workplace as well as elsewhere are reviewed regularly with employees. 
0. Lessons learned from

$\begin{array}{llllllllllll}1 & 2 & 3 & 4 & 5 & 6 & 7 & 8 & 9 & \begin{array}{l}10 \\ -.541\end{array} & & \end{array}$

incidents and injuries are

communicated to all relevant

people.

35. Safety rules and procedures

are regularly reviewed with

employees.

13. The results of safety audits

and inspections are regularly

shared with all employees.

91. Employees are kept informed

of the safety committees'

activities.

25. Employees are involved in

conducting safety audits and

inspections.

62. Improvements made from

employee safety suggestions are

communicated to all.

86. Employees help establish

and/or change safety rules,

regulations, policies, and/or

procedures.

15. The organization's safety

improvement goals and efforts are

regularly discussed with

employees.

11. When an employee is injured,

he or she will likely be punished

regardless of the causes and circumstances.

27. Senior managers place most of the blame for an injury on the injured employee.

33. Senior managers are more concerned about keeping the injury statistics low than with truly keeping people safe.

32. Senior managers do not put production ahead of safety. 


\begin{tabular}{|c|c|c|c|c|c|c|c|c|c|c|c|c|}
\hline $\begin{array}{l}\text { 23. My supervisor does not put } \\
\text { production ahead of safety. }\end{array}$ & 1 & 2 & 3 & 4 & 5 & 6 & 7 & 8 & 9 & 10 & 11 & $\begin{array}{l}12 \\
.697\end{array}$ \\
\hline $\begin{array}{l}\text { 38. Safety is not compromised } \\
\text { when determining production } \\
\text { schedules, overtime, and staffing. }\end{array}$ & & & & & & & & & & & & .475 \\
\hline $\begin{array}{l}\text { 34. Senior management } \\
\text { encourages preventive } \\
\text { maintenance instead of just } \\
\text { reacting to problems once they } \\
\text { occur. }\end{array}$ & & & & & & & & & & & & .416 \\
\hline
\end{tabular}


Table 4

Four Subfactor Intercorrelation Matrix on the 72 Extracted Items

\begin{tabular}{llllll}
\hline & & MC & PR & PS & SMS \\
\hline MC & Pearson Correlation & 1 & & & \\
PR & Pearson Correlation & $-.187^{* *}$ & 1 & & \\
PS & Pearson Correlation & $.573^{* *}$ & $.023^{* *}$ & 1 & 1 \\
SMS & Pearson Correlation & $.770^{* *}$ & $-.111^{* *}$ & $.673^{* *}$ & 1 \\
\hline
\end{tabular}

Note. $\mathrm{MC}=$ Management Concern for Safety; $\mathrm{PR}=$ Personal Responsibility for Safety; PS = Peer Support for Safety; SMS = Safety Management Systems ** Correlation is significant at the 0.01 level (2-tailed). 
Table 5

Hierarchical Confirmatory Factor Analysis Results: Tests of Model Fit

Comparable RMSEA (Root Mean SRMR

Fit Index Square Error of $\quad$ (Standardized

Approximation) Root Mean

Square Residual)

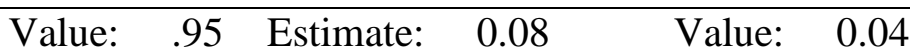

90 Percent C.I.

0.0820 .086 
Table 6

Theoretical Origin of Items and the Resultant Placement

\begin{tabular}{|c|c|c|}
\hline Survey Item \# & Theoretical Origin & EFA/HCFA Results \\
\hline Q1 & Safety Management System & Safety Management System \\
\hline Q2 & Management Concern & Management Concern \\
\hline Q3 & Management Concern & Supervisor Concern \\
\hline Q4 & Peer Support & Peer Support - Caution \\
\hline Q5 & Peer Support & Peer Support \\
\hline Q6 & Safety Management System & Safety Management System \\
\hline Q7 & Peer Support & Peer Support \\
\hline Q8 & Management Concern & Sr Management Concern \\
\hline Q9 & Management Concern & Sr Management Concern \\
\hline Q10 & Management Concern & Supervisor Concern \\
\hline Q11 & Safety Management System & Supervisor/Management Blame \\
\hline Q12 & Safety Management System & Safety Management System \\
\hline Q13 & Safety Management System & Communication \\
\hline Q14 & Safety Management System & Safety Management System \\
\hline Q15 & Safety Management System & Communication \\
\hline Q16 & Safety Management System & Safety Management System \\
\hline Q17 & Safety Management System & Safety Management System \\
\hline Q18 & Safety Management System & Discipline and Investigation \\
\hline Q19 & Safety Management System & Training and Rules \\
\hline Q20 & Safety Management System & Training and Rules \\
\hline
\end{tabular}


Survey Item \# Theoretical Origin

Q21 Safety Management System

Q22 Safety Management System

Q23 Management Concern

Q24 Safety Management System

Q25 Safety Management System

Q26 Safety Management System

Q27 Safety Management System

Q28 Management Concern

Q29 Safety Management System

Q30 Safety Management System

Q31

Q32

Q33

Q34

Q35

Q36

Q37

Q38

Q39

Q40

Q41

Q42
EFA/HCFA Results

Safety Management System

Discipline and Investigation

Work Pressure

Rewards and Recognition

Communication

Supervisor Concern

Supervisor/Management Blame

Supervisor Concern

Training and Rules

Supervisor Concern

Management Concern

Work Pressure

Supervisor/Management Blame

Work Pressure

Communication

Training and Rules

Safety Management System

Work Pressure

Management Concern

Communication

Safety Management System

Communication 


\begin{tabular}{|c|c|c|}
\hline Survey Item \# & Theoretical Origin & EFA/HCFA Results \\
\hline Q43 & Peer Support & Peer Support - Respectful Feedback \\
\hline Q44 & Safety Management System & Training and Rules \\
\hline Q45 & Safety Management System & Safety Management System \\
\hline Q46 & Safety Management System & Safety Management System \\
\hline Q47 & Safety Management System & Rewards and Recognition \\
\hline Q48 & Safety Management System & Training and Rules \\
\hline Q49 & Management Concern & Supervisor Concern \\
\hline Q50 & Safety Management System & Training and Rules \\
\hline Q51 & Safety Management System & Rewards and Recognition \\
\hline Q52 & Safety Management System & Rewards and Recognition \\
\hline Q53 & Safety Management System & Rewards and Recognition \\
\hline Q54 & Safety Management System & Safety Management System \\
\hline Q55 & Personal Responsibility & Risk Taking \\
\hline Q56 & Safety Management System & Rewards and Recognition \\
\hline Q57 & Safety Management System & Training and Rules \\
\hline Q58 & Safety Management System & Safety Management System \\
\hline Q59 & Safety Management System & Safety Management System \\
\hline Q60 & Management Concern & Risk Taking \\
\hline Q61 & Management Concern & Supervisor Concern \\
\hline Q62 & Safety Management System & Communication \\
\hline Q63 & Management Concern & Supervisor Concern \\
\hline Q64 & Safety Management System & Rewards and Recognition \\
\hline
\end{tabular}




\begin{tabular}{|c|c|c|}
\hline Survey Item \# & Theoretical Origin & EFA/HCFA Results \\
\hline Q65 & Safety Management System & Rewards and Recognition \\
\hline Q66 & Safety Management System & Peer Support - Respectful Feedback \\
\hline Q67 & Safety Management System & Risk Taking \\
\hline Q68 & Management Concern & Risk Taking \\
\hline Q69 & Safety Management System & Discipline and Investigation \\
\hline Q70 & Peer Support & Peer Support - Respectful Feedback \\
\hline Q71 & Personal Responsibility & Incident Reporting \\
\hline Q72 & Safety Management System & Incident Reporting \\
\hline Q73 & Personal Responsibility & Peer Support - Caution \\
\hline Q74 & Personal Responsibility & Incident Reporting \\
\hline Q75 & Peer Support & Peer Support - Caution \\
\hline Q76 & Personal Responsibility & Peer Support - Caution \\
\hline Q77 & Safety Management System & Training and Rules \\
\hline Q78 & Safety Management System & Rewards and Recognition \\
\hline Q79 & Personal Responsibility & Risk Taking \\
\hline Q80 & Personal Responsibility & Risk Taking \\
\hline Q81 & Peer Support & Peer Support - Caution \\
\hline Q82 & Peer Support & Peer Support - Caution \\
\hline Q83 & Safety Management System & Discipline and Investigation \\
\hline Q84 & Safety Management System & Risk Taking \\
\hline Q85 & Safety Management System & Communication \\
\hline Q86 & Safety Management System & Communication \\
\hline
\end{tabular}


Survey Item \# Theoretical Origin

Q87 Safety Management System

Q88 Safety Management System

Q89

Q90

Q91

Q92
Safety Management System

Peer Support

Safety Management System

Peer Support
EFA/HCFA Results

Discipline and Investigation

Discipline and Investigation

Safety Management System

Peer Support - Caution

Communication

Peer Support - Respectful Feedback

Note $. \mathrm{EFA}=$ Exploratory Factor Analysis; HCFA = Hierarchical confirmatory factor anaylsis. The items which are repeated from the theoretical origin placement in the results section, were extracted from the EFA or removed from the HCFA for rational reasons. 


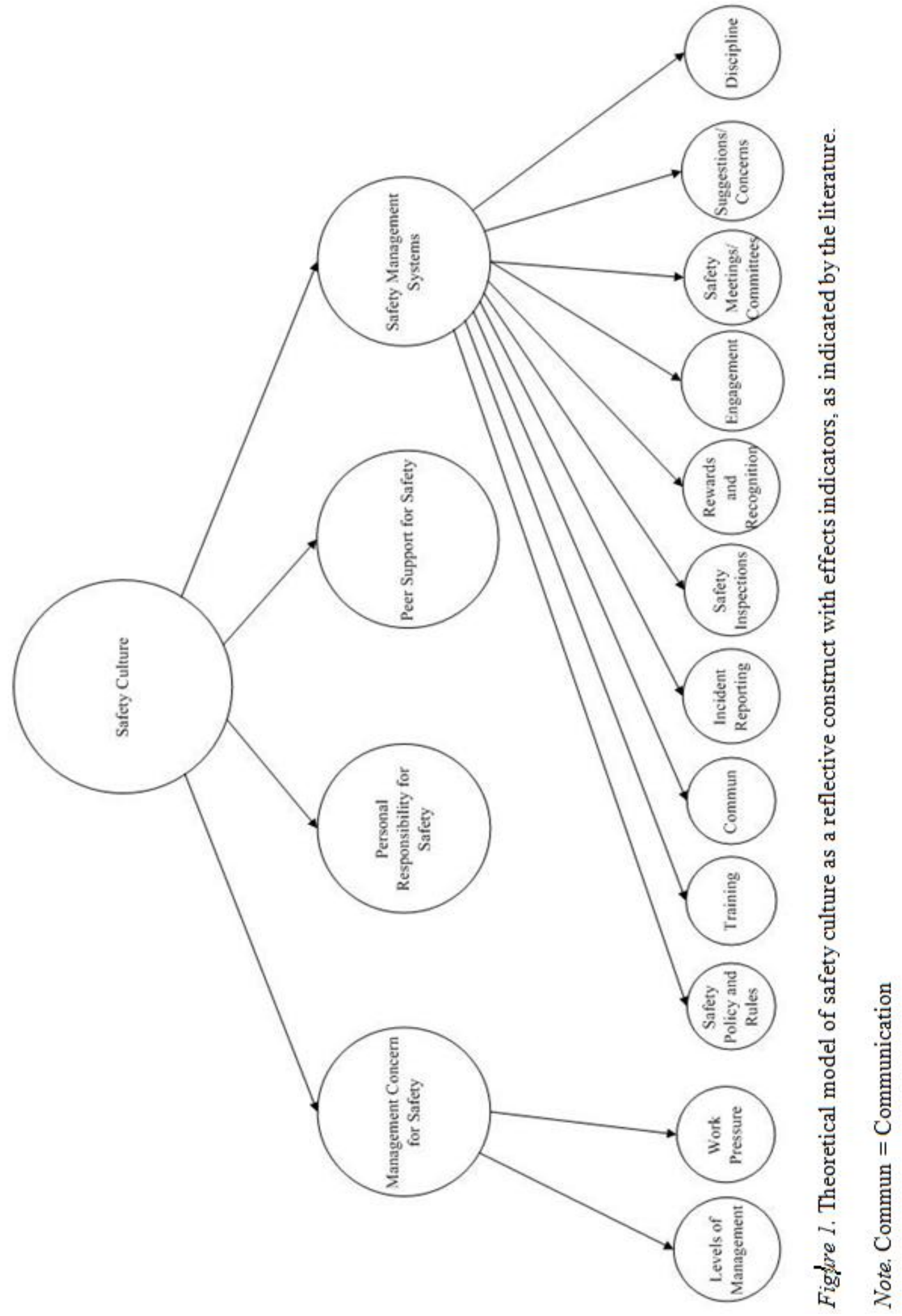




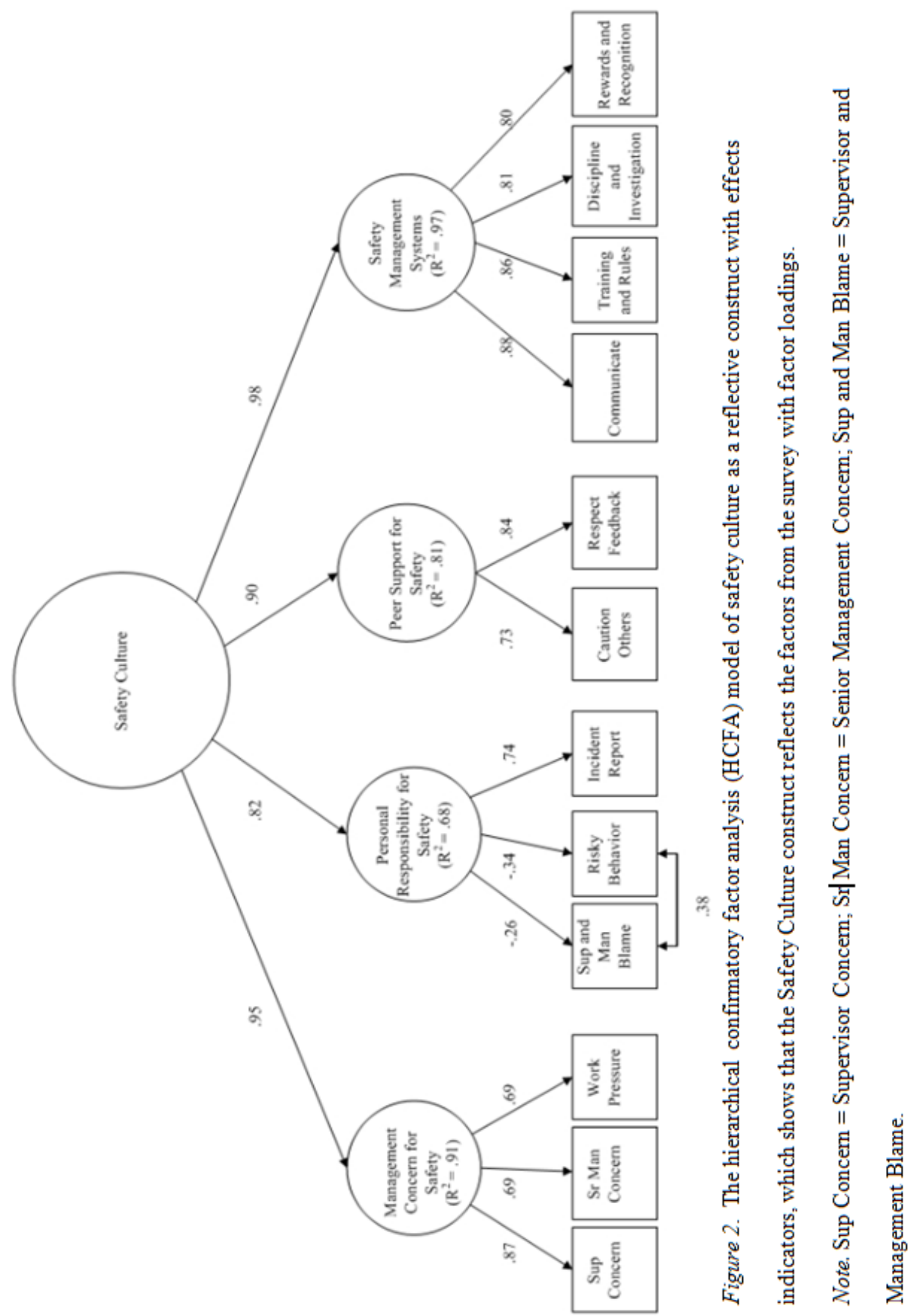




\section{VITA}

Christopher Brian Frazier was born and raised in Charlottesville, Virginia. Once he graduated from The Covenant School in 2005, he attended James Madison University where he studied Psychology, minored in statistics, and had a concentration in behavior analysis. While at James Madison, he was inducted as a member of the Lambda Chi Alpha fraternity and the Psi Chi psychology honors society.

He presented undergraduate research on the regional level at the University of Virginia and the Virginia Association for Behavior Analysis at James Madison University and served as a Teaching Assistant during his final year. After graduating in May, 2009, he enrolled at Appalachian State University to pursue his Master's degree in Industrial/Organizational Psychology and Human Resource Management. While at Appalachian State, he served as a Graduate Teaching Instructor and presented research on the national level at the Organizational Behavior Management Network Conference in Tampa, Florida. He received his Master's of Arts in May 2011 and will be seeking employment upon graduation. 